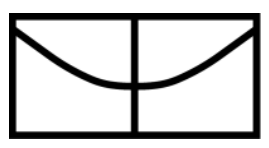

Universidade de Brasília

Instituto de Relações Internacionais

Carlos André Bezerra de Góes

Identidades em liberdade: mensurações quantitativas e reflexões teóricas sobre identidade nacional e integração regional na Europa 


\author{
Universidade de Brasília \\ Instituto de Relações Internacionais
}

Carlos André Bezerra de Góes

\title{
Identidades em liberdade: mensurações quantitativas e reflexões teóricas sobre identidade nacional e integração regional na Europa
}

\begin{abstract}
Monografia apresentada à Banca Examinadora do Instituto de Relações Internacionais da Universidade de Brasília como exigência final para obtenção do título de Bacharel em Relações Internacionais
\end{abstract}

Orientador: Prof. Dr. Carlos Pio 
Identidades em liberdade: mensurações quantitativas e reflexões teóricas sobre identidade nacional e integração regional na Europa

Carlos André Bezerra de Góes

BANCA EXAMINADORA

Prof. Dr. Carlos Pio - IREL/UnB

(Orientador)

Prof. Dr. Paulo Nascimento - IPOL/UnB

Prof. ${ }^{\text {a }}$ Dr. ${ }^{\text {a }}$ Patrice Schuch - DAN/UnB 
À memória de Larissa Ormond Fraga - que faz sempre com que eu mantenha minha fé incondicional na bondade essencial de todas as pessoas -, e a Átila da Veiga, irmão para toda a vida, que me ensinou que o amor verdadeiro transforma as pessoas e pode, regado a muitas e muitas lágrimas, vencer a própria morte. 


\section{AGRADECIMENTOS}

Agradeço a Deus - e a seu Cordeiro -, pelo Dom da Vida, da Razão e, especialmente, por me recordar diuturnamente que foi para Liberdade que Ele nos libertou (Gal. 5:1). Agradecimento essencial é também aqueles foram meu firmamento nas últimas duas décadas: minha mãe, Dulce Ane B. Góes - que fez da vida sempre mais doce com seu amor verdadeiro; a meu pai, José R. R. Góes - que me ensinou a importância da dedicação aos detalhes e sempre acreditou (e lutou) pelos meus sucessos; minha avó, Dulcinéa Oliveira - que é grande exemplo de força e fé; e minha irmã, Lídia Raquel - que, sem saber, reflete com sua jovem vida o quão gratos devemos ser pelas oportunidades que temos.

Entre os mestres preciso fazer um agradecimento especial a meu orientador, Carlos Pio, que trava uma luta libertária (e, por conseguinte, pela Liberdade, Paz e Desenvolvimento) em ambiente hostil à produtividade - e, exatamente por esta razão, exerce papel fundamental. Agradeço aos professores mais próximos, que me impulsionaram à frente - Leandro Couto, Ana Flávia Barros, Daniel Jatobá, Eiiti Sato, Julie Schmied e Cristina Yumie -, e a todos aqueles que ajudaram-me a evoluir - Geórgia Diogo, Alcides Vaz, A.C. Lessa, Débora Messenberg, Patrice Schuch, Mª Helena Santos, J.F.S. Saraiva, Ma . Izabel Carvalho, Mariza Velloso, Luciene Dias, Elizeu Chaves, Thiago Gehre, Ricardo Pereira, Teresa França Hussein Kalout e Terezinha Castro, dentre outros.

Preciso dizer que sempre me senti privilegiado por poder conviver em um ambiente formado por pessoas tão brilhantes quanto Relações Internacionais na UnB: todos têm opinião própria, argumentam em favor de suas opiniões e fundamentam-nas de forma coerente. Isso fazia com dos debates de sala (ou das conversas regadas a uma boa cerveja no Pôr-do-Sol) momentos únicos de aprendizado. Também por este motivo, preciso agradecer a muitos que contribuíram para o meu crescimento, mesmo sabendo que cometerei a injustiça de esquecer vários: Lolô, Heitor, Saulo, Beraba, Ivan, Tiê, Camila, Lya, Bruno, Nina, Rebecas, Sarreta, Bola, Luana, Acácio, Pet, Dimas, Gusman, Lucas Freitas, Rodrigo Randig, Martorelly, Marcel, Adriano (in memoriam), Márcio, Bruno, Nick, Carlota, Rafa, Bela Martins, Chico Venâncio, Luiza Goiana, Pimpão, Isa Garcia, Lalis (in memoriam), Sergipe, Lucas Negão, todos os Relnekens e Relscores, Tábata, Welton, Caio C., Maranhão, Bela G., Amanda, Caio L., Henrique, Marina, Tony, Raíssa, Leila, Saulo Said, Joana, Paraná, Maurício Dias, Glauben, Vallú, Léo Pinheiro, Penna, Kelson, Gabriel Negão, Chico Amorim, Zecchin, Toni Deitos, Mari Catunda, Lira, Gui, João, Edinho e Cássio, dentre outros.

Por fim, preciso fazer um distinto agradecimento a André Maia - por ter me dado a lição fundamental de que pessoas são só pessoas e todo o resto é semântica; a Fábio de Castro - que me ensinou que tudo na vida deriva do equilíbrio entre ousadia e responsabilidade; a André Delmiro - ao ter me mostrado que a amizade verdadeira transcende instituições; e a Dani Alano, Átila da Veiga e Raduan van Velthem - por terem sido esquadros nos momentos difíceis e júbilo dobrado nas celebrações.

Eu e minha pena somos hoje consequência da mistura de todas essas pessoas. 
Desdichadamente para los hombres, el planeta ha sido parcelado en países, cada uno provisto de lealtades, de queridas memorias, de una mitología particular, de derechos, de agravios, de fronteras, de banderas, de escudos y de mapas. Mientras dure este arbitrario estado de cosas, serán inevitables las guerras. Soy un cosmopolita que atraviesa fronteras porque no le gustan. Yo creo que sólo existen los individuos: todo lo demás, las nacionalidades y las clases sociales son meras comodidades intelectuales.

Jorge Luis Borges 


\section{RESUMO}

Essa monografia trata da influência das identidades nacionais europeias sobre o processo de integração regional característico do continente. Em termos mais objetivos, pretende-se testar a hipótese, amplamente disseminada no discurso político e nas mídias de massa, de existir uma correlação entre identidades nacionais mais arraigadas e uma rejeição ao aprofundamento da integração regional. Adicionalmente, pretende-se investigar a possibilidade de multi-identidade no espaço europeu e compreender se existe algum tipo de identidade europeia - bem como se esta necessariamente rivalizaria com as identidades nacionais. Subsidiariamente, objetiva-se traçar uma abordagem duplamente sintética entre o construtivismo social da Teoria das Relações Internacionais e (1) uma nova leitura do passado da disciplina; e (2) conceitos de disciplinas correlatas das Ciências Sociais - de modo a aperfeiçoar o instrumental teórico de Relações Internacionais e possibilitar a análise de identidades nacionais como fenômeno das relações internacionais contemporâneas. Para atingir esses objetivos, traça-se inicialmente uma análise teórica e uma revisão qualitativa sobre o fenômeno no espaço europeu e posteriormente testa-se estatisticamente, com base em dados do Eurobarômetro, as postulações previamente estabelecidas.

Palavras-chave: (1) Identidade Nacional; (2) Integração Regional; (3) União Europeia. 


\begin{abstract}
This dissertation regards the influence of European national identities over regional integration processes that characterizes the European Union. It will be tested the hypothesis which postulates a correlation between stronger national identities and negative behavior towards deeper regional integration. Such hypothesis is widely disseminated throughout political discourse and mass media. Furthermore, it will be researched if there is a possibility for multiple identities within the European space. What is more, it will be scrutinized the possible existence of a European identity and its alleged rivalry with national identities. Secondarily, it will be proposed a synthetic approach between social constructivism in International Relations Theory and (1) a revisionism of the discipline's past; and (2) concepts of other Social Sciences. Such synthetic approach aims at perfecting IR's theoretical framework and making viable an analysis of national identity as a phenomenon of contemporary international relations. In order to achieve these goals, it is initially done a qualitative revision of these phenomena in Europe. Afterwards, the qualitative conclusions will be statistically tested based on Eurobarometer's data.
\end{abstract}

Keywords: (1) National Identity; (2) Regional Integration; (3) European Union. 


\section{SUMÁRIO}

$1 \underline{1 N T R O D U C C A ̃ O} \quad 11$

$\underline{2}$ IDENTIDADE NA CONTEMPORANEIDADE: INDIVIDUALIDADE E LIBERDADE

2.1 IDENTIDADE E RELAÇÕES INTERNACIONAIS: LEGADO E LIMITAÇÕES DO CONSTRUTIVISMO SOCIAL 14

2.1.1 REVISITANDO O PASSADO: COMO OS CLÁSSICOS E O LIBERAL-INSTITUCIONALISMO PODEM CONTRIBUIR PARA O APRIMORAMENTO TEÓRICO DO CONSTRUTIVISMO SOCIAL 19

2.1.2 INDO ALÉM DAS LIMITAÇÕES: UMA ABORDAGEM SINTÉTICA E ABRANGENTE 28

2.2 IDENTIDADE NACIONAL: DAS CONSTRUÇÕES TEÓRICAS À CONSTRUÇÃO DA REALIDADE 32

2.3 ENTRE BAUMAN E BADIE: O INDIVÍDUO MULTI-IDENTITÁRIO 36

$\underline{3}$ IDENTIDADE E SOLIDARIEDADE NA EUROPA: REVISANDO A HISTÓRIA RECENTE E DELIMITANDO OS DESAFIOS À MULTI-IDENTIDADE

3.1 UMA HISTÓRIA JURÍDICO-INSTITUCIONAL: CIDADANIA, IDENTIDADE E LIBERDADE NA UE 42

3.2 CONFLITOS E DISCURSOS: OS DESAFIOS À EUROPA MULTI-IDENTITÁRIA 48

$4 \underline{\text { MENSURAC̄ÕES E TESTES QUANTITATIVOS SOBRE IDENTIDADE NACIONAL NA EUROPA } 53}$

4.1 Multi-IDENTIDAde COMO REALIDAde ESTATística No ESPAÇO EUROPEU 53

4.2 ISOLANDO A IDENTIDADE NACIONAL COMO VARIÁVEL: TESTES INDEPENDENTES PARA VERIFICAR POSSÍVEIS CORRELAÇÕES $\quad 60$

$\underline{5}$ CONCLUSÕES $\quad 68$

$\underline{6}$ BIBLIOGRAFIA $\quad 71$

$\begin{array}{lll}7 & \text { APÊNDICE } & 77\end{array}$ 


\section{ÍNDICE DE FIGURAS}

Figura 1 - Representação do construtivismo social estruturalista e estatocêntrico.

Figura 2 - Tentativa de rompimento com o estatocentrismo e estruturalismo para o estudo de ideias e identidades em RI.

Figura 3 - Estrutura identitária coletivista de base raciológica.

Figura 4 - Estrutura identitária coletivista de base classista. 38

Figura 5 - Exemplo de redes identitárias coletivas formando, em sua justaposição, a identidade individual 39

\section{ÍNDICE DE GRÁFICOS}

Gráfico I - Algum grau de identificação vs. Nenhum grau de identificação com a Europa. 56

Gráfico II - Identidade Europeia Líquida 57

Gráfico III - Identidade Europeia Líquida, por país 58

Gráfico IV - Índice Ponderado de Identidade 59

Gráfico V-Percepção sobre a UE para respondentes que têm identificação exclusiva com a nação 64

Gráfico VI-Percepção de benefício com a UE para respondentes que têm identificação exclusiva com a nação 65

Gráfico VII - Sentimento quanto ao possível fim da UE para respondentes que têm identificação exclusiva com a nação 66

\section{ÍNDICE DE TABELAS}

Tabela 1 - Multi-identidade e Estado-Nação 60

Tabela 2 - Dados Brutos do Eurobarômetro e coeficientes de correlação entre variáveis 63 


\section{Introdução}

O estudante de Relações Internacionais (RI) atento perceberá, em algum momento de sua trajetória, que há algo peculiar em toda bagagem teórica que delimita sua disciplina. Desde seu ingresso na Academia, ao ser introduzido às teorias mais tradicionais, o infante internacionalista é tutelado a aprender que o conceito de Estado é essencial para a compreensão de qualquer fenômeno no "sistema internacional" definido, desde aquele primeiro momento, como seu laboratório. Afinal, como se poderia falar relações internacionais sem que o Estado-Nação seja elemento constitutivo do próprio campo de estudos?

A despeito da evolução da Teoria de Relações Internacionais (TRI), por meio de sínteses e cismas entre suas diversas correntes, aqueles que influenciam o campo não conseguiram (ou não quiseram, ou não pretenderam) fazer o estudo da política internacional se despegar do estatocentrismo. Contudo, o mundo não é feito de Estados por decreto divino. Ao contrário, Estados são ficções jurídicas e intelectuais que só tomam forma antropomórfica por (quase) plena reificação de sua naturalidade pela maioria das pessoas - e, como dito, pelos próprios acadêmicos. Em última instância, o mundo é formado por indivíduos (neste caso, alguns creem que por ordem da Providência). De um modo apaixonado e elegante, alguns já lançaram - e começaram a responder - a pergunta fundamental: "onde estão as pessoas nas Relações Internacionais?" (Timo, 2010: 9).

Teorias são, para o acadêmico, o que são as ferramentas para um carpinteiro. Por mais talentoso que seja o artista, o êxito de seu trabalho somente será efetivo se ele puder contar com um afiado rol de instrumentos - preparados especialmente para enfrentar o material com que eles irão se deparar. Em muitos aspectos, a TRI é hoje como uma serra inapropriada para fazer os necessários recortes (teóricos) sobre sua matéria prima. Diversos elementos de relevância ímpar para as relações internacionais contemporâneas deixam de servir de matéria prima para o estudo teórico por inadequação instrumental. Com isso, todos perdem, já que tal situação implica em menor conhecimento sobre a própria realidade social.

A abordagem de identidades nacionais, foco essencial desta monografia, ficaria prejudicada sem avanços teóricos importantes. O principal deles é o rompimento do estatocentrismo típico de RI. Nações não têm vida, vontade ou identidade próprias. Elas 
são constituídas (e construídas) por indivíduos - que, exatamente por esse motivo, podem transformá-las e modificá-las dinamicamente.

Do mesmo modo, processos político-econômicos complexos e multifacetados como a integração regional são influenciados por uma miríade de agentes, como burocratas, lideranças sociais, políticos, empresários e lideranças sociais - que possuem, eles próprios, seus objetivos, interesses e agendas. Neste aspecto, como veremos, a literatura de Economia Política Internacional - no caso particular, de teoria da integração regional - avançou mais que a TRI.

O objetivo dessa monografia é investigar a influência das identidades nacionais europeias sobre o processo de integração regional característico do continente. Em termos mais objetivos, pretende-se testar a hipótese, amplamente disseminada no discurso político e nas mídias de massa, de existir uma correlação entre identidades nacionais mais arraigadas e uma rejeição ao aprofundamento da integração regional. Adicionalmente, pretende-se investigar a possibilidade de multi-identidade no espaço europeu e compreender se existe algum tipo de identidade europeia - bem como se esta necessariamente rivalizaria com as identidades nacionais.

Para atingir esses objetivos empíricos fundamentais, derivam dois outros objetivos, um teórico e outro ético. O objetivo teórico aponta para um sentido sintético, isto é, pretende-se superar as limitações teóricas da TRI traçando pontes entre a TRI e duas de suas margens: partes esquecidas de seu passado e suas disciplinas correlatas das Ciências Sociais. Com isso, objetiva-se ajudar a sanar as inadequações no atual instrumental teórico de RI, de modo a tornar possível analisar as identidades nacionais como fenômeno das relações internacionais contemporâneas.

O objetivo ético, por sua parte, é uma recordação ao próprio autor que a Academia não pode ficar isolada em uma distante (e empoeirada) torre de marfim. Como recorda Wendt (1998), o objetivo essencial da ciência é ontológico - e não metateórico. Nesse sentido, evidencia-se a meta de reverter a equação analítica usualmente utilizada para a relação entre integração regional e identidades nacionais. Ao invés de tomar os discursos de elites políticas como representações objetivas da realidade, deve-se tentar observar a posição dos indivíduos que compõem as distintas sociedades. Talvez não seja possível fazê-lo satisfatoriamente no escopo desta pequena pesquisa, mas o espírito do relato é, por certo, "ex parte populi” (Bobbio, 2000, cap. 1), 
isto é, apresentar uma perspectiva das RI que parte de uma visão do cidadão para falar sobre o que ocorre no plano dos Estados e do sistema internacional.

De modo a lograr atingir os objetivos relatados, esta monografia divide-se em três capítulos. O primeiro capítulo foca-se na abordagem sintética entre a TRI e suas disciplinas correlatas das Ciências Sociais, de modo a aprimorar o instrumental teórico necessário à análise das identidades nacionais como fenômeno das relações internacionais. Posteriormente, o segundo capítulo compreende uma revisão histórica e institucional da construção identitária no espaço europeu, bem como o relato e enfrentamento de alguns desafios objetivos e subjetivos à possibilidade multi-identitária na Europa. Finalmente, o último capítulo traz testes estatísticos realizados com o intuito de verificar com rigor formal as postulações e inferências qualitativas depreendidas até então - utilizando uma série de 25 surveys conduzidos pelo Eurobarômetro.

Apesar de seguir as recomendações Abdelal et. al. (2009) e ter optado por um método misto para compreender um fenômeno tão peculiar e subjetivo quanto identidade, deve-se reconhecer que as limitações fundamentais desta monografia são metodológicas. As aspirações (demasiadamente) amplas do autor não poderiam ser satisfeitas com os diminutos recursos disponíveis para este modesto empreendimento científico. Ainda assim, o autor acredita que as informações contidas nestas páginas têm relevância e podem contribuir, ainda que de forma precária, para o contínuo processo de destruição criativa (para parafrasear Schumpeter) que é típico da evolução científica. 


\section{Identidade na contemporaneidade: individualidade e liberdade}

Este capítulo tem por objetivo localizar a presente pesquisa na discussão teórica de Relações Internacionais (RI) bem como lançar os elementos conceituais necessários à compreensão das identidades nacionais, como fenômeno social intersubjetivo. Ademais, há um objetivo subsidiário, qual seja, o de construir pontes que ajudem superar determinadas limitações das Teoria das Relações Internacionais (TRI) para a compreensão de fenômenos identitários.

Inicialmente, será traçado o marco teórico de TRI, buscando explorar como questões identitárias e ideacionais têm sido tratada no escopa da disciplina. Posteriormente, serão introduzidas as construções teóricas da Teoria do Nacionalismo, desenvolvidas na Antropologia e Sociologia, para compreender como identidades nacionais podem ser estudadas. Finalmente, serão postos em diálogo Zygmunt Bauman e Bertrand Badie, de modo a elucidar quais foram as transformações ocorridas nas formações identitárias individual e coletiva e sintetizar em um modelo explicativo da multi-identidade na contemporaneidade.

\subsection{Identidade e Relações Internacionais: legado e limitações do construtivismo social}

A abordagem da presente investigação se aproxima, em muitos aspectos, da agenda de pesquisa construtivista em RI. A “virada construtivista” (Checkel, 1998: 2) teve como sua característica mais essencial a problematização de identidades e interesses dos atores internacionais. Nesse sentido, elementos ideacionais intersubjetivos passariam a figurar como principal foco de análise da Teoria das Relações Internacionais. Como afirma Ruggie (1998: 856), o "social constructivism rests on an irreducibly intersubjective dimension of human action" (Ruggie, 1998: 856).

Existiria, portanto, um claro contraste com as perspectivas "racionalistas" (ou “positivistas") de TRI, que, por sua próprias bases epistemológicas, eram conduzidas a um utilitarismo materialista: interesses e identidades eram tidos como variáveis dadas e desnecessárias de qualquer problematização posterior (cf. Ruggie, 1998b). Assim, as falhas na concepção epistemológica implicavam em uma incapacidade na delineação ontológica de dinâmicas das relações internacionais. Era, portanto, o pacote 
epistemológico nomológico-dedutivo - denominado em RI, genericamente, de "positivismo" - que conduzia as abordagens tradicionais a um materialismo utilitarista.

É necessário considerar, nesse contexto, que desde o lançamento da clássica Theory of International Politics de Kenneth Waltz (1979), a própria disciplina se desenvolveu tomando o neorrealismo waltziano como seu centro de gravidade. Isso significa que uma parte significativa das grandes obras posteriores buscavam fazer concessões (cf. Keohane, 1984) ou se contrapor (cf. Wendt, 1999) àquele autor.

Waltz, dotado de uma perspectiva estatocentrista e estruturalista, teceu um elegante argumento em que afirmava que, para ser possível o delineamento de qualquer teoria geral da política (e dos conflitos) internacionais, as variáveis causais não poderiam estar nas características domésticas de cada Estado (cf. Waltz, 1979, cap. 2). Ao contrário, a explicação deveria repousar sobre a estrutura do sistema internacional caso contrário, a explicação seria "reducionista" e não poderia constituir uma teoria (geral) da política internacional. Waltz (1979: 100-101) resumiria sua teoria estruturalista com base em três pontos: (1) o princípio de organização do sistema internacional é anárquico, o que implica em ausência de hierarquia na cena internacional; (2) as unidades estatais são funcionalmente equivalentes, pois, em decorrência da anarquia internacional, todos os atores são levados a atuar com base na ideia de self-help ${ }^{1}$, buscando mais poder; e (3) existe uma diferença em termos de distribuição de capacidades entre os atores - e as mudanças nessa distribuição seria a única variável sistêmica para explicar as modificações dinâmicas no cenário internacional. Outrossim, segundo a lógica neorrealista os atores estatais seriam forçados pela estrutura anárquica do sistema internacional a competir egoisticamente por poder, de modo a buscar uma (nova) distribuição de capacidades mais favorável a si (ou a manutenção do status quo, caso este lhe seja favorável).

Nesse sentido, construtivistas como Alexander Wendt $(1992 ; 1999)$ desejavam apresentar uma resposta teórica satisfatória a Waltz, tendo como objetivo fundamental inserir elementos ideacionais e problematizar identidades e interesses na análise das RI.

\footnotetext{
${ }^{1}$ A ideia de self-help implica na noção de que qualquer Estado depende unicamente de si para manter sua segurança e para buscar uma melhor situação internacional. "For the realist the notion of self-help is a logical consequence of the anarchical structure of international states-system ... Given that states are independent political units that are primarily concerned with their own survival and advancement but are not subordinate to a central authority, the idea of self-reliance is a compelling one. The search for security in a system of politics without government means that self-help is a necessary function of selfpreservation.” (Evans \& Newham, 1998: 499)
} 
Não por acaso há uma grande semelhança entre os magnus opus de Waltz e Wendt este último batizou o seu de Social Theory of International Politics. Wendt tenta traçar as diferenças entre sua perspectiva e a de Waltz logo no começo de seu livro, ao afirmar que o construtivismo social possui

"[...] two basic tenets [...]: (1) that the structures of human association are determined primarily by shared ideas rather than material forces, and (2) that the identities and interests of purposive actors are constructed by these shared ideas rather than given by nature. The first represents an 'idealist' approach to social life, and in its emphasis on the sharing of ideas it is also 'social' in a way which the opposing 'materialist' view's emphasis on biology, technology, or the environment, is not. The second is a 'holist' or structuralist' approach because of its emphasis on the emergent powers of social structures, which opposes the 'individualist' view that social structures are reducible to individuals. Constructivism could therefore be seen as a kind of 'structural idealism'." (Wendt, 1999: 1) [grifo nosso].

Não obstante, existe um par de deficiências fundamentais que limitam a possibilidade de pesquisa construtivista em RI, quais sejam: (1) a retenção do estruturalismo waltziano, ainda que direcionado a estruturas ideacionais; e (2) a adesão construtivista a um estatocentrismo analítico, isto é, a exclusão de indivíduos, grupos de pressão, burocracias e corporações como objetos de análises.

De fato, o estruturalismo está na própria raiz do construtivismo social em Ciências Sociais. Se Waltz (1979: 106) afirma que "structures encourage certain behavior and penalize those who do not respond to the encouragement", Berger \& Luckmann (1966), autores da seminal The Social Construction of Reality, dizem que

The character of the self as a social product is not limited to the particular configuration the individual identifies as himself (for instance, as "man," in the particular way in which this identity is defined and formed in the culture in question), but to the comprehensive psychological equipment that serves as appendage to the particular configuration (for instance, "manly" emotions, attitudes and even somatic reactions). It goes without saying, the, that the organism and, even more, the self cannot be adequately understood apart from the particular social context in which they are shaped (Berger \& Luckman.1966: 50)

Onuf (1989) e Wendt (1987: 335) tentaram flexibilizar o determinismo estruturalista por meio da adoção da teoria da estruturação "to prevent structural reification". Não obstante tal postulação, pôde-se observar uma tendência à prevalência de uma estrutura 
social em linhas similares à estrutura material waltziana - conforme explicitado na supracitado trecho de Wendt (1999: 1).

A tendência de Nicholas Onuf (1989: 129-144) ao estruturalismo social se expressa mais em seu foco sobre a institucionalização e internalização de normas, papéis e prescrições sociais. Embora afirme que "people always construct, or constitute, social reality" (Onuf, 1989: 1), seu foco se dá nos padrões de condicionamento das ações individuais às prescrições sociais.

\footnotetext{
Detached supervision would supplant direct applications of violence to secure compliance with another's will, expressed abstractly in the form of rules. Sanctions are therefore depersonalized in social practice as well as conventionalized in theory ... The myth of voluntarism complements the myth of neutrality (Onuf, 1989: 192-195).
}

Wendt (1999), por sua parte, procura dialogar diretamente com o neorrealismo estruturalista de Waltz. Identifica, todavia, um novo tipo de estrutura, rejeitando o materialismo proposto pelo neorrealismo. Afirma que "[t]he most important move is to reconceptualize what international structure is made of. In my view it is exactly what Waltz says it is not: a social rather than material phenomenon" (Wendt, 1999: 20). Ademais, afirma que a institucionalização das culturas compartilhadas pelos Estados como agentes internacionais - foi, em alguma medida, internalizada - enfatizando, ainda, a dificuldade de haver mudanças quando ocorrida a institucionalização (Waltz, 1999: cap. 6).

O estatocentrismo, por sua parte, fica patente na impossibilidade de análise de quaisquer concepções que tenham outros atores que não o Estado como foco dos estudos internacionais. Wendt chega a afirmar que é irrelevante discutir a questão do estatocentrismo pois, para ele, dizer que um teórico de RI é estatocentrico seria algo análogo a denominar um botânico de "tree-centric" (1999: 9). Nesse sentido, embora construtivistas problematizem identidades e interesses, estas serão identidades e interesses de Estados e não dos grupos ou indivíduos que compõem aquele estado - o que Wendt denomina como “corporate identity” (Cf. Wendt, 1994).

O estruturalismo estatocentrista do construtivismo disseminado na TRI pode ser expresso conforme a Figura 1, que representa um sistema simples de quatro Estados $\left(E_{A}\right.$, $\left.E_{B}, E_{C}, E_{D}\right)$, as relações entre eles $(\rightarrow)$, e as condicionantes estruturais que sobre eles atuam. Embora construtivistas argumentem que, ao contrário de neorrealistas, seu 
modelo estrutural é ideacional, ainda existe o foco nas condicionantes estruturais sobre a ação internacional dos Estados. As possibilidades de mudança sistêmica ficam prejudicadas, uma vez que a estrutura predomina sobre a ação voluntária dos agentes, restando unicamente uma possibilidade de transformação exógena que, de fato, ainda figura como vácuo teórico a ser explorado. Afora isso, qualquer abordagem que considere atores que não a figura estatal ficam prejudicados, uma vez que não se concebe a possibilidade de atuação internacional relevante de qualquer agente que não sejam os Estados.

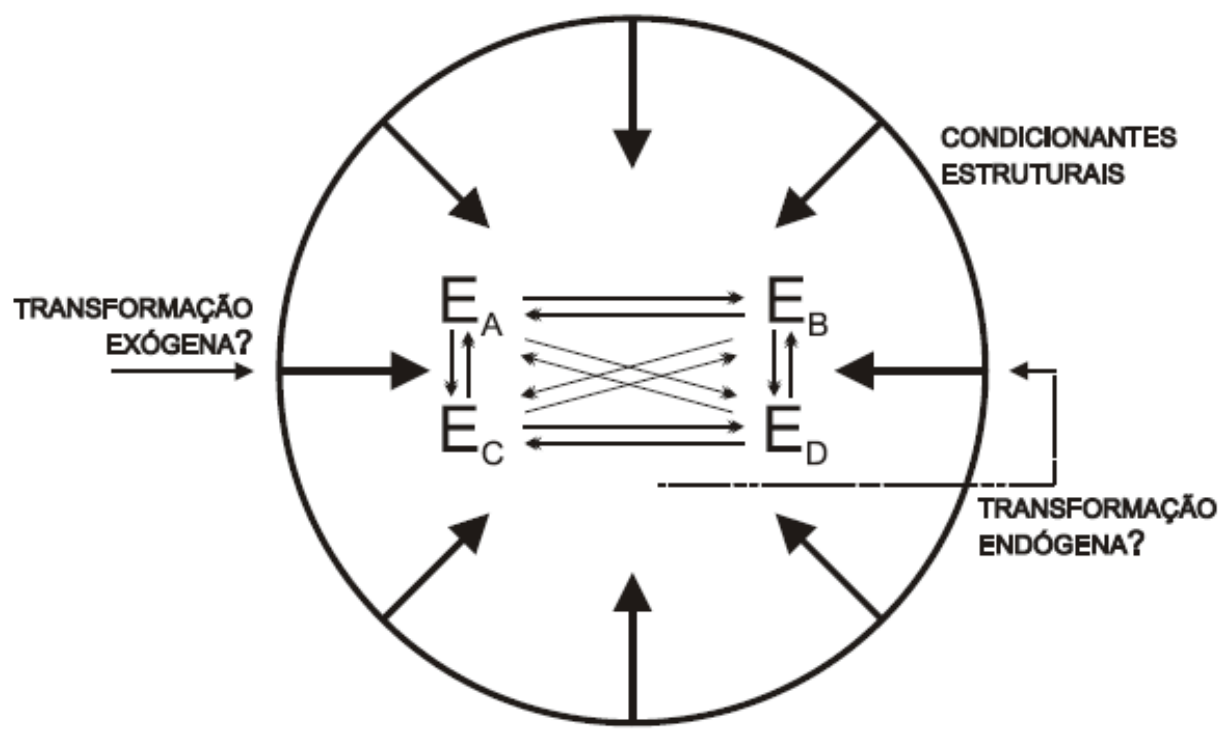

Figura 1 - Representação do construtivismo social estruturalista e estatocêntrico. (Elaboração própria, com inspiração em Waltz, 1979)

O construtivismo estatocêntrico objetiva tomar como variável analítica as identidades e interesses de Estados - ambos construídos socialmente pela interação internacional com outros agentes. Entretanto, essa abordagem desconsidera que Estados são ficções jurídicas que não tem qualquer identidade ou interesse per se. Ademais, a soma do estruturalismo à equação analítica construtivista implica no fato de se ignorar que a postulação identitária de qualquer grupo pode derivar mais de dinâmicas sociais domésticas (ou da contínua interação de diversos ambientes domésticos com dinâmicas internacionais) do que de supostas determinantes estruturais-sistêmicas internacionais.

Ambas as limitações são relevantes para a presente pesquisa, pois têm impacto significativo para a compreensão de fenômenos como a identidade nacional - que partem de um método individualista para a compreensão da construção identitária. Nesse sentido, existe uma inadequação na TRI para a abordagem desses fenômenos. 
Argumenta-se aqui que para a devida compreensão das identidades nacionais como variável relevante das relações internacionais contemporâneas é necessário avançar no sentido da superação do estruturalismo e estatocentrismo construtivistas. De tal sorte, o esforço aqui empreendido é, ao mesmo tempo, um tributo ao legado construtivista - uma vez que pretende-se avançar nos objetivos primordiais dessa agenda de pesquisa - e uma forte crítica à estruturação teórica do construtivismo social em RI.

De modo a tornar possível uma nova perspectiva quanto à consideração de questões identitárias nas RI, e tentar superar as limitações do estatocentrismo e estruturalismo, pretende-se traçar uma abordagem duplamente sintética. Por uma parte, objetiva-se revisitar o passado esquecido da disciplina para fazer uma nova leitura rejeitada pelos construtivistas. O mito fundador do construtivismo quanto a sua inovação ontológica da consideração de elementos ideacionais leva a uma leitura problemática do passado da disciplina. Nesse sentido, é necessário revisitar o passado da disciplina e aprender lições importantes para uma melhor adequação teórica do próprio construtivismo social. Por outra parte, é preciso dialogar com disciplinas correlatas das Ciências Sociais e tomar emprestado delas conceitos e métodos, de modo a aprender como tratar a identidade em novos contextos já explorados por estas disciplinas.

Este capítulo se esforçará no sentido de traçar a supracitada abordagem duplamente sintética. Esta seção focar-se-á na primeira metade desta empreitada, revisitando o passado da disciplina e traçando os fundamentos teóricos para a superação das limitações do construtivismo social em RI.

\subsubsection{Revisitando o passado: como os clássicos e o liberal-institucionalismo podem contribuir para o aprimoramento teórico do construtivismo social}

Como recorda Steve Smith (1995), toda disciplina forma sua(s) própria(s) autoimagem(ns), baseadas em uma leitura específica sobre seu passado e em mitos fundacionais essenciais para a reconstrução da genealogia da disciplina - ou de mudanças importantes na história desta. Aquele que talvez seja o mito fundador mais importante da "virada construtivista" nas RI seja a reinvindicação, por parte dos 
construtivistas, de estes terem sido responsáveis uma grande inovação ontológica, qual seja, a consideração de elementos ideacionais como variáveis relevantes para as RI.

Por uma parte, o supracitado mito fundador construtivista reflete o esforço dessa corrente no sentido de colocar no centro do debate teórico a problematização de identidades e interesses. Tal esforço tem, de fato, grande relevância para o avanço da disciplina e destaca uma característica distintiva da agenda construtivista.

Por outro lado, a mesma leitura implica na desconsideração do fato de que diversos autores, muito antes da "virada construtivista", deram atenção à análise de elementos ideacionais nas RI. Autores clássicos, como Hans Morgenthau ou Raymond Aron, e diversos autores da tradição liberal-institucionalista - ao contrario do que afirma o mito fundacional construtivista - consideram ideias como variáveis importantes para a compreensão das RI.

Nesse sentido, argumenta-se aqui que uma releitura do passado literário da disciplina pode render frutos importantes para uma readequação teórica do construtivismo social e para a superação dos limites impostos pelo estruturalismo e o estatocentrismo. De tal sorte, pretende-se, ao final da revisão teórica, poder traçar uma abordagem sintética entre os fundamentos construtivistas e os avanços até então ignorados esquecidos no passado da disciplina.

Ao iniciar uma releitura sobre o passado das RI como disciplina teórica, é possível observar que, mesmo que de forma tangencial, questões identitárias e ideacionais sempre fizeram-se presentes no estudo das relações internacionais. Em uma breve genealogia, seria possível identificar esse tipo de raciocínio ainda no relato de Tucídides sobre a Guerra do Peloponeso, em que este argumentava ser a percepção ${ }^{2}$ do aumento do poder Atenas e o temor que tal percepção infligiu sobre os Lacedemônios que tornou

\footnotetext{
${ }^{2}$ Sendo uma percepção é, portanto, uma ideia e não necessariamente uma assertiva factual.
} 
a guerra inevitável (cf. Lebow, 2001). Contemporaneamente, dentre os escritos clássicos das Relações Internacionais, tanto Raymond Aron quanto Hans Morgenthau, embora ícones do realismo político, fazem assertivas inesperadas para quem imagina que a consideração específica de ideias, identidades e interesses somente teriam sido introduzidas na disciplina pelo construtivismo social ${ }^{3}$.

Raymond Aron utiliza termos que seriam encarados com naturalidade no léxico de diversos construtivistas contemporâneos: "[o] comportamento dos Estados não é orientado exclusivamente pela relação de forças: as ideias e os sentimentos influenciam as decisões dos atores internacionais" (Aron, 1962: 159) ${ }^{4}$. Naturalmente, os termos utilizados pelos autores clássicos são distintos daqueles que, contemporaneamente, se tomam como típicos do discurso construtivista. Não obstante, a interpretação do texto pode prover elementos para uma analogia. Aron expressa claramente que valores compartilhados e padrões de conduta institucionalizados entre determinados Estados e sociedades - algo que, no léxico construtivista, poder-se-ia chamar de "percepções intersubjetivas" - têm influência determinante sobre a dinâmica da política internacional.

Vai mais além, ao discutir laços de solidariedade que possam existir, por advento de princípios compartilhados, entre Estados e cidadãos de outras nacionalidades: “[h]á um

\footnotetext{
3 Ashley (1986) reconhece que Morgenthau não era estruturalista, como era Waltz. Entretanto, não percebe em sua análise que as nuances do realismo clássico de Morgenthau, ao não se basear na rigidez teórica behaviorista e optar por um método mais descritivo, consegue abordar em momentos específicos de sua Politics Among Nations situações em que o mesmo reconhecia que os Estados não tinham papel tão preponderante. De fato, ainda no primeiro capítulo de sua obra Morgenthau (1948) revela que sua principal preocupação é observar como os homens de Estado tomam decisão (reconhecendo o problemático antropomorfismo inerente do estatocentrismo). Ademais, Morgenthau revela um elemento normativo em sua teoria, ao reconhecer que as políticas externas nem sempre são racionais, mas afirmar que a boa política externa é racional.

${ }^{4}$ Aron faz a supracitada assertiva quando delineia uma divisão entre o que chama de sistemas homogêneos e heterogêneos, um corte que seria transversal à divisão entres sistemas uni- e multipolares. Tal divisão se define nos seguintes termos: "sistemas homogênos são aqueles que reúnem Estados do mesmo tipo, dentro de uma mesma concepção política. Sistemas heterogêneos são os que congregam Estados organizados segundo princípios diferentes, postulando valores contraditórios. [...] Um sistema homogêneo parece estável também porque é previsivel. Se todos os Estados têm regimes análogos, estes só podem ser tradicionais - formados pelo tempo, não improvisados. Em tais regimes, os estadistas obedecem regras provadas ou a costumes. Os rivais e os aliados desse Estado sabem, de modo geral, o que podem esperar dele (Aron, 1962: 159-160)".
} 
conflito ideológico quando cada campo professa uma idéia e os dois campos estão divididos, havendo em cada um deles um certo número de cidadãos que não querem a vitória de seu país, se ela representar a derrota que os orienta, e que está encarnada no inimigo" (Aron, 1962: 161). Nesse sentido, as percepções intersubjetivas emergiriam não somente da socialização de Estados, mas também das relações intersocietárias e transnacionais - algo que aponta para o sentido de superação do estatocentrismo.

Por sua parte, Hans Morgenthau, na própria obra referencial do realismo político, traz também observações que atribuem relevância ao papel das ideias e dos condicionamentos morais nas ações de Estados. Fá-lo, ademais, sem abdicar de uma concepção extremamente positivista da política internacional. Morgenthau argumenta que a política é regida por "leis objetivas que deitam suas raízes na natureza humana" (Morgenthau, 1948: 4). Sem embargo, garante espaço para as ideias em sua reflexão:

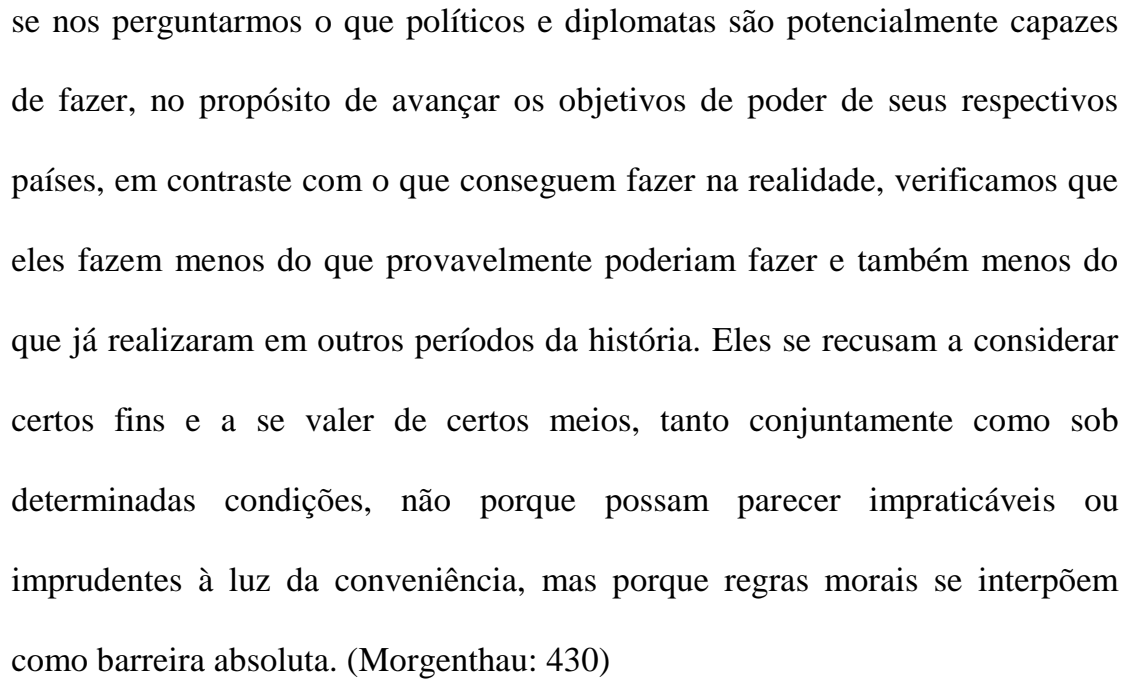

Morgenthau (1948: 609) corrobora com as percepções de Aron quanto ao fluxo intersocietário de ideias, ao afirmar que "durante o período monolítico do comunismo, os comunistas de todas as partes apoiavam as políticas externas da União Soviética”. 
Insere, ademais, uma nova vertente: o fluxo e o compartilhamento transgovernamental ${ }^{5}$ de valores e princípios.

Eles [os burocratas internacionais] se achavam vinculados por laços de família, por uma língua comum (francês), por valores culturais compartilhados, por modo de vida semelhante e convicções morais em comum sobre o que um cavalheiro podia ou não fazer com outro cavalheiro, fosse este da mesma ou de uma outra nacionalidade. Os príncipes que disputavam o poder consideravam-se como competidores em um jogo cujas regras eram aceitas por todos os demais competidores. (Morgenthau, 1948: 450) ${ }^{6}$

Nesse sentido, as solidariedades transgovernamentais são também constitutivas de um senso de identidade. Isso de fato acontece no processo de integração regional europeu, como será visto posteriormente, que é usualmente descrito como uma dinâmica de socialização de elites políticas ${ }^{7}$. Tais identidades são constructos intersubjetivos que influenciam, ademais, a "corporate identity" (cf. Wendt, 1994) postuladas para Estados, uma vez que as elites burocráticas têm maiores capacidades para fazer prevalecer determinado perfil identitário ou propagar determinada identidade oficial.

É possível encontrar também abordagens que podem contribuir para a superação dos limites do estatocentrismo e estruturalismo ao revisar a literatura liberal-institucionalista de RI. Nesta corrente, na análise sobre o papel das ideias nas relações internacionais destaca-se o estudo quanto ao impacto e função de instituições internacionais como

\footnotetext{
${ }^{5}$ Relações transgovernamentais devem ser compreendidas como a interação entre burocracias específicas de distintos Estados, quebrando a lógica do estatocentrismo e de Estados como atores unívocos.

${ }^{6}$ É bem verdade que Morgenthau tratava de um período bem específico, dos séculos XVII e XVIII, quando a diplomacia era regida por aristocracias específicas. Entretanto, uma vez estabelecido o princípio das percepções intersubjetivas compartilhadas por elites burocráticas, as diversas analogias seguem naturalmente.

${ }^{7}$ Ver Capítulo 2.
} 
variáveis intervenientes nas relações internacionais, especialmente os regimes internacionais (cf. Krasner, 1982).

A própria definição de regimes internacionais pressupõe o compartilhamento de ideias, expressas nos termos de princípios, normas, regras e procedimentos padronizados na tomada de decisão, que restringem as margens de manobra os atores, no mínimo, ao alterar custos de transação e cálculos de custo-benefício (cf. Krasner, 1982). Além disso, a expectativa de socialização de longo prazo entre os atores transforma o próprio princípio do self-help, tornando a busca egoísta por mudanças nas capacidades relativas em "myopic self-interest" (Keohane, 1984: 115) - isto é, a ideia de que, existindo instituições, a competição por poder pode render resultados subótimos que podem maximizados cooperando ainda que sob anarquia (Cf. Oye, 1986).

Não resta dúvida que, para Robert Keohane, regimes são processos de interação social, simbólica e material - em última instância, cultural.

This argument parallels Clifford Geertz`s discussion of how anthropologists should use the concept of culture to interpret societies they investigate. Geertz sees culture as the "webs of significance" that people have created for themselves. On the surface they are enigmatical; the observer has to interpret them so that they make sense. Culture, for Geertz, "is a context, something within which [social events] can be intelligibly described" (1973, p.14). [...] even in world politics human beings spin webs of significance. They develop implicit standards for behavior, some of which emphasize the principle of sovereignty and legitimize the persuit of self-interests, while others rely on quite different principles. Any act of cooperation or apparent cooperation needs to be interpreted within the context of related actions, and of prevailing expectations and shared beliefs, before its meaning can be properly understood. (Keohane, 1984: 56). [grifo nosso] 
Avançando no esforço teórico, o volume editado por Risse-Kappen (1995) procurou integrar a existência de atores não-estatais (como, por exemplo, Organizações NãoGovernamentais ou Comunidades Epistêmicas ${ }^{8}$ ) à teoria liberal-institucionalista, observando de que modo tais atores relacionavam-se com os regimes internacionais. A obra deu um importante passo, embora ainda tímido, no sentido do rompimento com o estatocentrismo. Fê-lo ao observar que atores não-estatais, por um lado, utilizam os regimes internacionais construídos previamente para legitimar suas ações no plano interno e, por outro, contribuem, eles próprios, para a formação dos regimes internacionais. De tal sorte, caminha-se para o sentido de postular atores não-estatais como "channels through which new ideas circulate from societies to governments as well as from country to country" (Haas, 1992: 27).

Outra perspectiva que dá passos mais largos rumo ao rompimento com o estatocentrismo e estruturalismo é o estudo de redes transnacionais, que abrange desde a ação de grupos da sociedade civil organizada para atingir objetivos como a preservação do meio ambiente ou a defesa dos direitos humanos até entidades terroristas como a Al-Qaeda ${ }^{9}$. Arquilla \& Ronfeldt (2001) postulam que as modificações estruturais nas comunicações e nas relações sociais da era da informação (Cf. Castells, 1997) favorecem o surgimento de organizações desprovidas de hierarquia, mas altamente dinâmicas, que possuem células (“nós”) que se adaptam rapidamente conforme as mudanças nos objetivos da rede. Ademais, os supracitados nós podem ser

\footnotetext{
8 "An epistemic community is a network of knowledge-based experts or groups with an authoritative claim to policy-relevant knowledge within the domain of their expertise. Members hold a common set of causal beliefs and share notions of validity based on internally defined criteria for evaluation, common policy projects, and shared normative commitments". (Haas, 1987: 223)

${ }^{9}$ De fato, tanto a literatura sobre relações transnacionais (Risse-Kappen, 1995) quanto a literatura sobre redes (Arquilla \& Ronfeldt, 2001) é herdeira do rompimento propiciado pela ideia de interdependência complexa, lançada por Nye \& Keohane (1977) como instrumento de análise alternativo ao realismo que tinha como pressupostos três princípios: (1) a existência de múltiplos canais conectando sociedades; (2) a ausência de hierarquia na agenda internacional; e (3) a impossibilidade (ou extrema dificuldade) do uso da força física nas relações internacionais.
} 
constituídos por grupos, burocracias ou até mesmo indivíduos ${ }^{10}-$ o que amplia o espectro de atores internacionais de forma significativa. Os autores tratam como essencial o papel das identidades e solidariedades entre os membros das redes, pois as definem como SPINs: "segmented, polycentric, ideologically integrated networks"11 (Arquilla \& Ronfeldt, 2001: 11).

Uma nova leitura dos autores clássicos e da literatura liberal-institucionalista de RI torna possível avançar no sentido da superação do estatocentrismo e do estruturalismo originário do neorrealismo waltziano e perene nas obras mais importantes do construtivismo social. A soma dos pequenos avanços dados por cada um dos autores permite formular um conjunto de quatro premissas teóricas que serão essenciais para o passo posterior, que é o rompimento com as limitações supracitadas. Essas premissas são:

(1) Estados não são atores unitários ou unívocos. As burocracias governamentais não agem, necessariamente, de forma coerente e organizada e muitas vezes competem entre $\mathrm{si}^{12}$. Tais burocracias, quando agem de forma independente na cena internacional, por vezes tomam posições muito distintas sobre o mesmo assunto;

(2) Estados não são os únicos atores internacionais. Burocracias governamentais, atores subnacionais (estados federados, municípios),

${ }^{10}$ Como não reconhecer que o protagonismo de Osama bin Laden no cenário internacional, suficientemente relevante a ponto de fazer com que bilhões de dólares dos contribuintes americanos fossem empreendidos em sua caçada, faz dele um ator internacional?

11 "By segmentary I mean that it is cellular, composed of many different groups. . . . By polycentric I mean that it has many different leaders or centers of direction. . . . By networked I mean that the segments and the leaders are integrated into reticulated systems or networks through various structural, personal, and ideological ties. Networks are usually unbounded and expanding. . . . This acronym [SPIN] helps us picture this organization as a fluid, dynamic, expanding one, spinning out into mainstream society". (Gerlach apud Arquilla \& Ronfeldt, 2001: 11)

${ }^{12}$ Em uma nota bem pessoal, posso afirmar que nas oportunidades que tive de participar de reuniões interministeriais do governo brasileiro (preparatórias para reuniões internacionais) em muitos casos, as burocracias governamentais têm muito mais afinidade - e maior facilidade de cooperar - com seus órgãos análogos de outros países do que com outras partes do governo brasileiro. 
parlamentos, empresas multinacionais, redes transnacionais, ONGs e indivíduos agem simultaneamente na arena internacional. Reconhecer este fato não implica em afirmar que governos nacionais não têm mais relevância nas relações internacionais contemporâneas. Ao contrário, governos nacionais ainda têm muita importância. Este reconhecimento implica unicamente na afirmação de que os Estados não são atores solitários no cenário internacional - como postulam tanto o neorrealismo de Waltz, quanto o construtivismo de Wendt;

\section{Múltiplos agentes contribuem para a disseminação de valores e}

identidades no cenário internacional. Existindo uma pluralidade de atores internacionais, não existe monopólio sobre a oferta internacional de valores e identidades. Estados contribuem para essa dinâmica acordando sobre Tratados e Convenções que, em grande medida, delimitam a existência dos regimes internacionais. Entretanto, burocracias governamentais ${ }^{13}$, empresas multinacionais ${ }^{14}$ e organizações da sociedade civil ${ }^{15}$ também têm participação nessa dinâmica - e podem tanto cooperar quanto rivalizar com

\footnotetext{
${ }^{13}$ Um bom exemplo de rede interburocrática que dissemina determinados valores é a Red Iberoamericana de Cooperación Jurídica Internacional, formada por Ministérios Públicos e Ministérios da Justiça dos países ibero-americanos que "está orientada a la optimización de los instrumentos de asistencia judicial civil y penal, y al reforzamiento de los lazos de cooperación entre nuestros países. Constituye así un paso fundamental en la conformación de un Espacio Judicial Iberoamericano, entendido como un escenario específico donde la actividad de cooperación jurídica sea objeto de mecanismos reforzados, dinámicas e instrumentos de simplificación y agilización en la consecución de un tutela judicial efectiva." Ver: www.iberred.org

${ }^{14}$ É claro exemplo da participação de empresas multinacionais em regimes multinacionais a formação do Processo de Kimberley para a Certificação de Diamantes Africanos. O Processo de Kimberley é um processo de certificação de diamantes destinado à eliminação da comercialização de diamantes de conflito. O Processo contou não somente com a presença de Estados, mas com um papel preponderante do World Diamond Council, a associação das maiores produtoras mundiais de diamantes. Nesse sentido, o regime internacional dele advindo não dependia exclusivamente da ação estatal, mas também de agentes nãogovernamentais.

${ }^{15}$ A forte atuação da sociedade civil organizada nas Conferências das Partes da Convenção Quadro das Nações Unidas sobre Mudanças Climáticas evidencia essa situação. A simples presença desses grupos é uma oferta de identidades, no sentido em que sua participação pode levar outros indivíduos, sejam eles burocratas ou não, a aderirem às suas causas. Além disso, a atuação desses mesmos grupos nos EUA fez com que alguns estados federados, como a Califórnia, aprovassem legislações que determinavam sistemas de limitação de gases de efeito estufa, mesmo à revelia do governo federal americano.
} 
as opções dos governos nacionais. A inexistência de monopólio para oferta de valores e identidades no cenário internacional significa que este espaço está sempre aberto para contestabilidade por parte de outros tipos de valores ou identidades; e

(4) Não existe uma estrutura internacional coerente (ideacional ou material) que determine a ação dos atores internacionais. De fato, existe uma multiplicidade de sistemas ideacionais que convivem simultaneamente na cena internacional. Tais sistemas podem ser próximos e complementares ou distantes e rivais e podem variar desde, por exemplo, um regime de nãoproliferação de armas exclusivamente estatal até a ideia de uma jihad universal que modifica comportamentos de indivíduos em diversas partes do globo. De fato, ao invés de concordar com Wendt (1992) para afirmar que Anarchy is What States Make of It, pode-se dizer que a anarquia é o que as pessoas (e o que elas acreditam) fazem dela - estejam estes indivíduos no governo, organizações internacionais, empresas multinacionais, ONGs ou redes transnacionais.

A releitura de um passado esquecido da disciplina de RI permite agregar pequenos avanços em quatro premissas, conforme foi feito acima. Estas premissas não são, por si só, um modelo alternativo ao estatocentrismo e ao estruturalismo neorrealismo ou construtivista. Entretanto, elas constituem os fundamentos básicos para a postulação desse novo modelo.

\subsubsection{Indo além das limitações: uma abordagem sintética e abrangente}

Quais seriam as implicações da existência de tais limitações ao estudo empírico do nacionalismo como fenômeno das relações internacionais? Inicialmente, ao privilegiar 
uma postura estruturalista, elimina-se qualquer possibilidade de discussão sobre voluntarismo na forma de identidades coletivas e individuais - algo que se tornou parte importante como referencial na Teoria do Nacionalismo. Ademais, uma postura estatocêntrica exclui stateless nations como unidades de análise e diverge significativamente das evoluções mais recentes em outros campos das Ciências Sociais que exploram o fenômeno do nacionalismo, tais como a Antropologia, a Sociologia ou a História.

Nesse sentido, é preciso avançar para um novo modelo que rompa com o estatocentrismo e o estruturalismo na consideração de ideias e identidades nas relações internacionais. Com nos quatro pressupostos traçados no capítulo anterior, derivados de conceitos de autores clássicos e liberal-institucionalistas, é possível buscar uma expansão para tal estudo, tal como expresso na Figura 2. Tomando como exemplo um sistema simples que envolva dois governos ${ }^{16}\left(G_{A}\right.$ e $\left.G_{B}\right)$ e duas sociedades $\left(S_{A}\right.$ e $\left.S_{B}\right)$, monta-se um quadro de fluxos ideacionais e identitários $(\rightarrow)$ entre distintos atores internacionais, que onde se pode considerar:

(1) a formação doméstica de identidades e interesses com base na interação dinâmica de grupos e o fluxo inverso de políticas oficiais para a institucionalização de identidades e interesses;

(2) o fluxo de ideias e identidades existente em relações intersocietárias e transnacionais;

(3) o fluxo de ideias e identidades existente em relações intergovernamentais e transgovernamentais;

16 "Governos", neste caso, incluem tanto as relações diplomáticas tradicionais ("relações intergovernamentais") quanto a interação entre burocracias governamentais que retêm algum grau de interdependência em sua ação internacional ("relações transgovernmentais"). Ambos os conceitos foram tomados de Nye \& Keohane (1977: 29-30). 
(4) a influência das diversas interações sobre a formação e consolidação de instituições, princípios, valores e expectativas, i.e., ideias compartilhadas intersubjetivamente;

(5) o fluxo de ideias e identidades existente entre parte de uma sociedade e um outro governo; e

(6) a influência das percepções intersubjetivas institucionalizadas sobre a formação de identidades e interesses dos atores múltiplos internacionais.

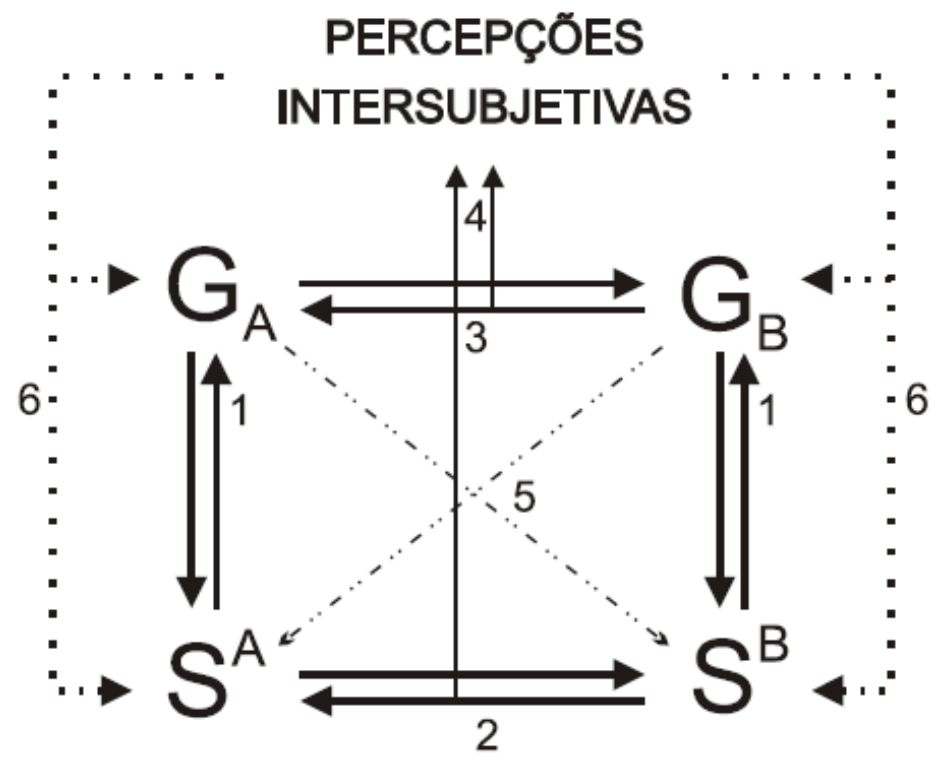

Figura 2 - Tentativa de rompimento com o estatocentrismo e estruturalismo para o estudo de ideias e identidades em RI. (Elaboração própria).

Embora seja possível traçar referenciais teóricos objetivos na TRI para problematizar identidades e interesses, visando estudar de forma plena o fenômeno do nacionalismo (e da identidade nacional), é preciso romper algumas limitações das correntes dominantes dentre as Teorias de Relações Internacionais contemporâneas. Nesse sentido, deve-se observar que há uma díade de limitações fundamentais nas abordagens mais influentes, tanto construtivistas quanto racionalistas. 
Por uma parte, aquelas abordagens que conseguiram ir além das limitações do estruturalismo waltziano, mesmo que tenham ensaiado a consideração de elementos ideacionais, não tinham como seu foco primário de análise e reflexão a problematização de interesses e identidades dos distintos atores. Por outro lado, o ramo de reflexões derivado do construtivismo social, que reivindica para si a primordial inovação ontológica da inserção de identidades e interesses como objeto de estudo nas Relações Internacionais, ficaram presos ao estatocentrismo e estruturalismo que impede qualquer estudo que tenha como foco indivíduos ou que considere a interação entre indivíduos e grupos.

De tal sorte, para o estudo de identidades e interesses, individuais e coletivos, de um tipo peculiar para as TRI - tal como a identidade nacional -, faz-se necessária uma abordagem duplamente sintética. Primeiramente, é necessário fazer uma síntese entre a preocupação construtivista quanto a identidades e interesses sendo fatos de consciência constituídos socialmente e a superação do estatocentrismo e individualismo de correntes derivadas do neoliberalismo institucional ${ }^{17}$. Ao mesmo tempo, é necessário incorporar, também de forma sintética, conceitos já desenvolvidos em campos correlatos das Ciências Sociais, que possam ser úteis a este tipo de reflexão.

O esquema proposto nesta seção, conforme explicitado pelo diagrama representado pela Figura 2, é um esforço no sentido de avançar no sentido da primeira abordagem sintética - dentre distintas teorias de RI. Nas próximas duas seções será empreendido o esforço de trazer para diálogo com as RI conceitos fundamentais da Teoria do Nacionalismo e filosofia, pois somente com a articulação concertada dos conceitos forjados em ambas as disciplinas é possível um estudo mais apurado do supracitado fenômeno.

\footnotetext{
${ }^{17}$ Isso significaria buscar algo similar ao que fizeram diversos autores clássicos, como supracitado, mas de modo mais metódico e teórico e menos descritivo
} 


\subsection{Identidade nacional: das construções teóricas à construção da realidade}

Ainda em meados do século passado, Karl Deutsch (1968, cap. 1) já alertava que a temática de "identidade e transformação" seria um dos grandes desafios para o estudo das relações internacionais contemporâneas. Não é, portanto, qualquer surpresa perceber que o próprio Deutsch foi um pioneiros em suas reflexões quanto à importância da identidade nacional nas relações internacionais (Deutsch, 1966). Em sua época, ainda era pouco frutífera tal reflexão.

Todavia, o cenário mudou significativamente em favor de uma larga disseminação de estudos e teorias. Como ilustra Hobsbawm (1990: 11), em seu humor peculiar, se um historiador intergalático pousasse na Terra, ele chegaria à conclusão de que seria impossível compreender o mundo sem compreender o termo nação. O historiador inglês complementa dizendo que hoje seria possível alcançar tal compreensão através de leituras de um campo de estudos específico, algo que seria dificilmente realizável no último século (cf. Hobsbawm, 1990: 11-13).

É disseminado o argumento de as identidades nacionais serem construções discursivas que pressupõem a intolerância em relação a outros grupos que não o nacional (v., p.ex., Finzsch \& Schirmer, 1998). Também na mídia e no discurso político pode ser observada tal linha argumentativa: um artigo de um relevante periódico britânico relata, por exemplo, a necessidade de que haja uma rejeição do nacionalismo por parte dos líderes políticos europeus (The Independent, 2002).

Historicamente, é razoável afirmar que essa visão tenha sido reforçada pela ampla propagação do que se pode denominar de concepção naturalista do nacionalismo. Segundo esta concepção, a nação seria um ser vivo, um ente natural, independente das relações sociais existentes entre os membros da mesma. A nação estaria evidente na língua, na raça, no território, na fidelidade ao grupo, nos costumes, na cultura, nas antigas tradições. A qualificação de um grupo social como nação não seria relacionado à existência de um sentimento nacional, mas sim aos elementos como os supracitados.

Que tais agrupamentos não tenham consciência de sua solidariedade, que não manifestem o desejo de viver em comum, pouco importa: os sinais exteriores constituem critério indiscutível (Renouvin \& Durroselle, 1967).

Essa abordagem tangencia argumentos antigos e recentes. A ideia de "espaço vital”, delineada por Friedrich Ratzel (1897) ao fim do século XIX em sua 
Antropogeographie, argumentava em favor da "ligação natural" de determinados espaços territoriais como destinados ao povo germânico, racialmente definido esperando somente sua conquista. Ludwig von Mises (1909: 34-35) concordava com a ideia da nação ser um ente natural, expressa na comunhão linguística, mas partia individualismo metodológico para sua conclusão:

[t]he word and concept nation belong completely to the modern sphere of ideas of political and philosophical individualism; they win importance for real life only in modern democracy. If we wish to gain insight into the essence of nationality, we must proceed not from the nation but from the individual. We must ask ourselves what the national aspect of the individual person is and what determines his belonging to a particular nation. [...] Yet we must insist that just as the concepts nation and race do not coincide, so national policy and race policy are two different things. Also, the concept of race, in the sense in which the advocates of race policy use it, is new, even considerably newer than that of nation. It was introduced into politics in deliberate opposition to the concept of nation. The individualistic idea of the national community was to be displaced by the collectivist idea of the racial community.

Uma das expressões teóricas mais recentes da concepção naturalista do nacionalismo reside no conceito de nacionalismo étnico de Antony Smith (1993), que logrou moldar conceitualmente cenários que concebessem o caráter dinâmico das identidades nacionais e não ficasse restrito ao determinismo estático. A identidade nacional seria baseada em identidades étnicas seculares, definindo ethnies como "named human populations with shared ancestry myths, histories and cultures, having an association with an specific territory and a sense of solidarity" (Smith, 1993: 32).

[Smith] insiste em que a realidade objetiva de uma ethnie passada realmente importa para as nações modernas. Sem o que ele denomina "complexos mitológico-simbólicos", que geram e expressam a identidade étnica, o nacionalismo moderno seria desprovido de raízes e arbitrário. O intelectual ou o político nacionalistas modernos baseiam-se em identidades étnicas existentes. (Breuilly, 2000: 159)

Afora isso, as experiências dos coletivismos nazifascistas do Século XX, concebidos com base em premissas naturalistas raciológicas, reforçaram supracitada ideia do nacionalismo intolerante. Contemporaneamente, ainda é possível identificar ecos dos argumentos raciológicos, como observado pelo discurso do Presidente Armênio Robert Koharian, em 2003, em que se proclamava a existência de uma “incompatibilidade étnica" entre azeris e armênios. 
Mais recentemente, disseminou-se nos estudos culturais uma concepção construtivista do nacionalismo, que compreendia a identidade nacional - e a ideia de nação - como um fato de consciência fruto de um contexto econômico-social específico.

The literature on nationalism associated with Karl Deutsch, Ernest Gellner, Benedict Anderson, and others represents perhaps the best developed "case study" of the social construction of an identity-namely, national identity. These authors reject the primordialist view of nations as historically immanent, arguing instead that the idea of nationality became compelling to people only in the modern period as a result of economic and attendant social changes. (Fearon and Laitin, 2000: 851)

Deutsch (1966) afirmava que a nação era percebida por uma comunidade identitária que estava ligada por meio de redes de comunicação social e que tinha sua solidariedade forjada com base em elementos como a língua, a etnia e a percepção de uma história e destino comuns. Esses fatores seriam manipulados e distorcidos por meio de elites políticas com projetos nacionalistas e seriam, para Karl Deutsch, os "building blocks" da nacionalidade.

Ernest Gellner (1983), por sua parte, traça uma explicação funcionalista para o surgimento das nações. Na modernidade elites políticas teriam incentivo para buscar estabilidade e unidade por meio da padronização de métodos técnicos e educacionais. Segundo Gellner, nações são uma necessidade imposta pela complexificação das relações sociais derivadas da modernidade e da mudança da sociedade agrária para industrial. Em termos normativos, a definição de nação que Gellner traça acaba por tender ao voluntarismo intersubjetivo, ao afirmar que:

(1) Two men are of the same nation if and only if they share the same culture, where culture means in turn a system of ideas and signs and associations and ways of behaving and communicating; (2) Two men are of the same nation if they recognize each other as belonging to the same nation. In other words, nations maketh men; nations are the artifact of men's convictions and loyalties and solidarities (Gellner, 1983 [2006]: 6-7).

Benedict Anderson traz aquela que talvez seja a mais completa expressão da concepção construtivista do nacionalismo. Nos dizeres de Anderson (1983 [2001]: 5-6) a nação seria "an imagined political community - and imagined both inherently limited and sovereign". Limitada pois aí reside aí diferença entre o compatriota e o estrangeiro; soberania que se reflete no objetivo fundamental de autogoverno. Nesse sentido, devese ressaltar a ideia de que a nação não é algo existente ex nihilo, mas algo construído 
socialmente, por meio das mídias e das relações sociais. Em última instância, uma nação só existiria nas mentes e nos corações de seus cidadãos - a nação seria, antes de tudo, a consciência da nação. É marcante, nesse sentido, um famoso discurso de Ernest Renan (1882), onde o mesmo relata que:

Uma nação é portanto uma grande solidariedade, constituída pelo sentimento advindo dos sacrifício que nós fazemos e estamos dispostos a fazer no futuro. Ela pressupõe um passado resultante em um fato tangível: o consentimento, o claro e expresso desejo de continuar a conviver em sociedade. A existência da nação é, em si mesma, um plebiscito diário, assim como a própria existência do indivíduo é uma perpétua afirmação da vida.

De tal modo, mesmo reconhecendo a importância dos fatores tidos como fontes naturais da nação para a emergência de um sentimento nacional, eles por si só não seriam suficientes. Sem a expressão de uma identidade comum, de um sentimento de solidariedade, não pode haver nação. Isto, pois a nação seria constituída exatamente por esta identificação coletiva sendo, assim, uma comunidade imaginada.

No presente trabalho será dada preferência à abordagem construtivista da Teoria do Nacionalismo. A explicação para tal escolha reside em duas razões fundamentais. Inicialmente, tal abordagem é a mais aceita e a mais disseminada entre acadêmicos que se dedicam ao estudo da identidade nacional - a despeito de algum ressurgimento do naturalismo após o trabalho de Anthony Smith quanto ao nacionalismo étnico. De modo similar, ao menos desde a obra clássica de Clifford Geertz (1985), parte significante da antropologia social dedica-se à interpretação dos modos de significação que indivíduos dão à sua realidade social imediata ${ }^{18}$.

A outra razão para a prevalência dessa abordagem é sua afinidade com o construtivismo social de TRI - precisamente a escola que mais travou diálogos com fenômenos de integração regional. Uma preocupação fundamental desta pesquisa, tal qual a agenda de pesquisa construtivista, é analisar possíveis influências da constituição identitária (individual e coletiva) sobre a formação de interesses e perceber se diferenças

\footnotetext{
${ }^{18} \mathrm{Na}$ famosa citação: "The concept of culture I espouse, and whose utility the essays below attempt to demonstrate, is essentially a semiotic one. Believing, with Max Weber, that man is an animal suspended in webs of significance he himself has spun, I take cultures to be those webs, and the analysis of it to be therefore not an experimental Science in search of law but an interpretative one in search of meaning" (Geertz, 1985: 5). De fato, os primórdios do rompimento da antropologia social com qualquer abordagem naturalista são muito anteriores. Evans-Pritchard (1940) versava sobre a mudança situacional (e, portanto, modos ideacionais de formação identitária) de solidariedade entre os Nuer. Afora isso, mesmo Tylor, no século XIX, já falava sobre cultura como um todo adquirido.
} 
quanto à estruturação plural e situacional das referidas identidades modificam a constituição desses interesses.

Outrossim, embora reconhecendo, como Risse (2010: 21), "social identities can also be extremely consensual and acquire qualities of a social taboo" argumenta-se que "[even though] many ethnonationalist identities are constructed in such a way that they resemble primordial identities, they remain [social] constructions" (Ibidem).

\subsection{Entre Bauman e Badie: o indivíduo multi-identitário}

Relaxando-se a ideia do primordialismo determinista da concepção naturalista da identidade nacional, bem como o estruturalismo e o estatocentrismo disseminado entre as TRI, é possível lançar as bases para a compreensão de questões identitárias no mundo contemporâneo. A questão identitária na contemporaneidade apresenta, em termos teórico e empírico, mudanças objetivas em relação ao momento histórico imediatamente anterior, que necessitam de efetiva compreensão para uma análise de suas reverberações sobre os processos de integração regional ora sob escrutínio.

Um referencial conceitual importante para compreender a modificação das questões identitárias é lançada por Zygmunt Bauman (2000), por meio da diferenciação entre a Modernidade Sólida, vigente quando da época dos coletivismos, e a Modernidade Líquida, característica da contemporaneidade. Complementarmente, podese lançar mão da análise feita por Bertrand Badie (1995) quanto ao relaxamento das identidades territoriais, essencialmente ligadas ao Estado-Nação, em face a novas identidades, desterritorializadas, que têm surgido como consequência da ampla disseminação de novos métodos de comunicação.

A Modernidade Sólida, sendo característica da era dos coletivismos e das coletivizações forçadas, tinha como um de seus traços fundamentais a existência de uma identidade primordial sobre a qual estruturavam-se identidades subsidiárias. A identidade fundamental era, contudo, inegociável e prioritária, dando pouco espaço a voluntarismos individuais para qualquer escolha ou postulação de sua própria identidade.

Essa modernidade pesada/sólida/condensada/sistêmica [...] era impregnada de uma tendência ao totalitarismo. [Era a modernidade da] sociedade totalitária da homogeneidade compulsória, imposta e onipresente [...] Essa modernidade era 
inimiga jurada da contingência, da variedade, da ambiguidade, da instabilidade, da idiossincrasia, tendo declarado uma guerra santa a todas essas "anomalias"; e esperava-se que a liberdade e a autonomia individuais fosse as primeiras vítimas da cruzada (Bauman, 2000: 33).

"Na época em que foi escrito, o 1984 de George Orwell era o mais completo - e canônico - inventário dos medos e apreensões que assombravam a modernidade em seu estado sólido" (Bauman, 2000: 34). A imposição total de identidades ia além dos arroubos ideológicos dos coletivismos nazifascista e comunista - firmou bases também sobre os primordialismos nacionais, conforme demonstrado pelas interpretações naturalistas da identidade nacional. "Essas visões supunham que a questão identitária era, a priori, regulada pela instituição da cidadania: lealdade primeira e superior a todas as outras, esta regulava naturalmente todos os comportamentos do indivíduo no seio do espaço público" (Badie, 1995: 119).

[A tese primordialista pressupõe] a afirmação triunfante das identidades perenes e da certeza que os 'grupos naturais' transcendem o tempo e o espaço [...] O argumento supõe já que se elevem, pela força da autoridade, determinados entes coletivos à dignidade de unidades irredutíveis da história do mundo. [...] Assim, o primordialismo dissimula mal a volatilidade das construções identitárias que têm também, frequentemente, uma origem e uma função de protesto contra uma ordem política dotada de sucessos, de legitimidade ou de capacidade distributiva limitadas. (Badie, 1995: 123-4).

Em suma, pode-se dizer que as postulações identitárias da Modernidade Sólida eram tidos como fatos dados, perenes e prioritários; entidades coletivas naturais que sobrepõem-se a qualquer potencial identidade rival, colocando-se a identidade primordial como estrutura fundamental para outros tipos identitários subsidiários. Ademais, sua perenidade explica-se pela reclamação de existência histórica desde tempos imemoráveis e pela expectativa de existência futura eterna, sem quaisquer modificações possíveis nas estruturas identitárias - vez que essas são dadas e não construídas. Exemplos de postulações identitárias típicas da Modernidade Sólida estão expressas na Figura 3 e na Figura 4. 


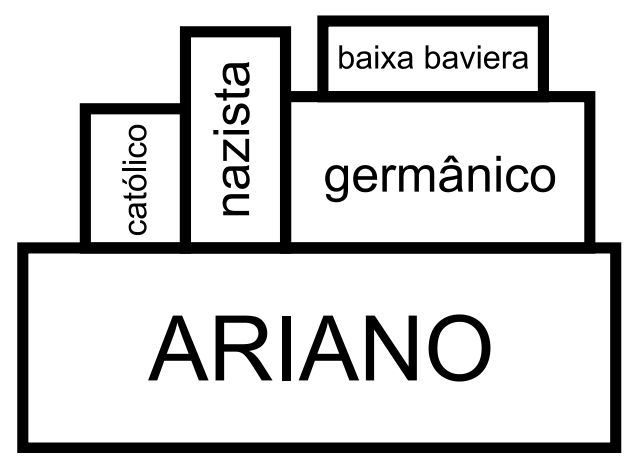

Figura 3 - Estrutura identitária coletivista de base raciológica. (Elaboração própria)

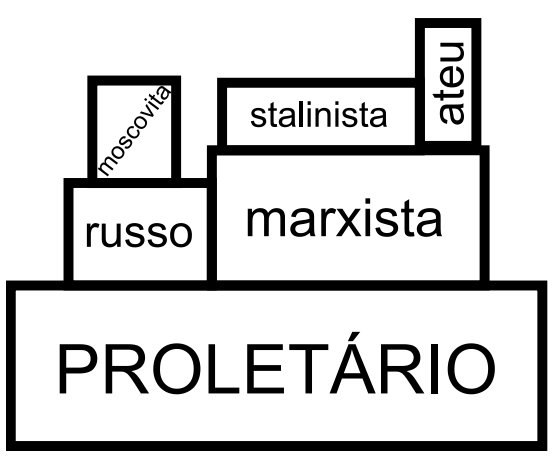

Figura 4 - Estrutura identitária coletivista de base classista. (Elaboração própria)

As estruturas identitárias da Modernidade Sólida contrapõem-se à fluidez das identidades encontradas no período tardio da modernidade. Esse cenário é caracterizado por um maior voluntarismo na escolha quanto ao pertencimento individual às redes de solidariedade identitária. "Não se surpreende que não mais se escrevam distopias nestes tempos: o mundo pós-fordista, 'moderno fluido', dos indivíduos que escolhem em liberdade, não se ocupa mais do sinistro Grande Irmão, que puniria os que saíssem de linha" (Bauman, 2000: 73).

É a capacidade de 'ir às compras' no supermercado das identidades, o grau de liberdade genuína ... de selecionar a própria identidade e de mantê-la enquanto desejado, que torna o verdadeiro caminho para a realização das fantasias da identidade. Com essa capacidade, somos livres para fazer e desfazer identidades à vontade. Ou assim parece. (Bauman, 2000: 98)

Nesse sentido, em tal cena, os indivíduos podem construir sua identidade singular na justaposição de múltiplas redes identitárias coletivas. A construção da identidade individual peculiar significa, portanto, a escolha de tipos identitários que variam em qualidade - i.e. identidades ideológica, nacional, local, comunitária, sexual, religiosa, etc. -, quantidade - i.e. o acúmulo de vários tipos identitários do mesmo grupo qualitativo -, e prioridade - i.e. um ordenamento situacional para as múltiplas identidades. Ao contrário da coletivização do indivíduo existente quando da existência das postulações identitárias primordialistas, a identidade na contemporaneidade enfocase no voluntarismo e, portanto, na pluralidade e na sigularidade das diversas identidades individuais. Esse esquema é exemplificado, de forma simplificada, na Figura 5.

De tal sorte, faz-se mister enfatizar que há uma significativa distinção nos processos de construção e expressão de individualidades multi-identitárias em espaços repressivos quanto às escolhas individuais ou sob liberdade. Em um cenário onde sejam 
favorecidas as liberdades individuais e coletivas - compreendidas, conforme Hayek (1960), como ausência de coação quanto à escolha e ação de indivíduos e associações de indivíduos - torna-se facilitada a possibilidade de livre escolha de múltiplas identidades complementares. Considerando que uma das características da Modernidade Líquida é a destruição dos totalitarismos coletivistas (típicos da Modernidade Sólida) e a liberdade de escolha individual - ou, nos dizeres de Bauman (2001) o surgimento de uma "sociedade individualizada" - , torna-se evidente que esse parece o desenho adequado para a construção identitária individual na contemporaneidade.

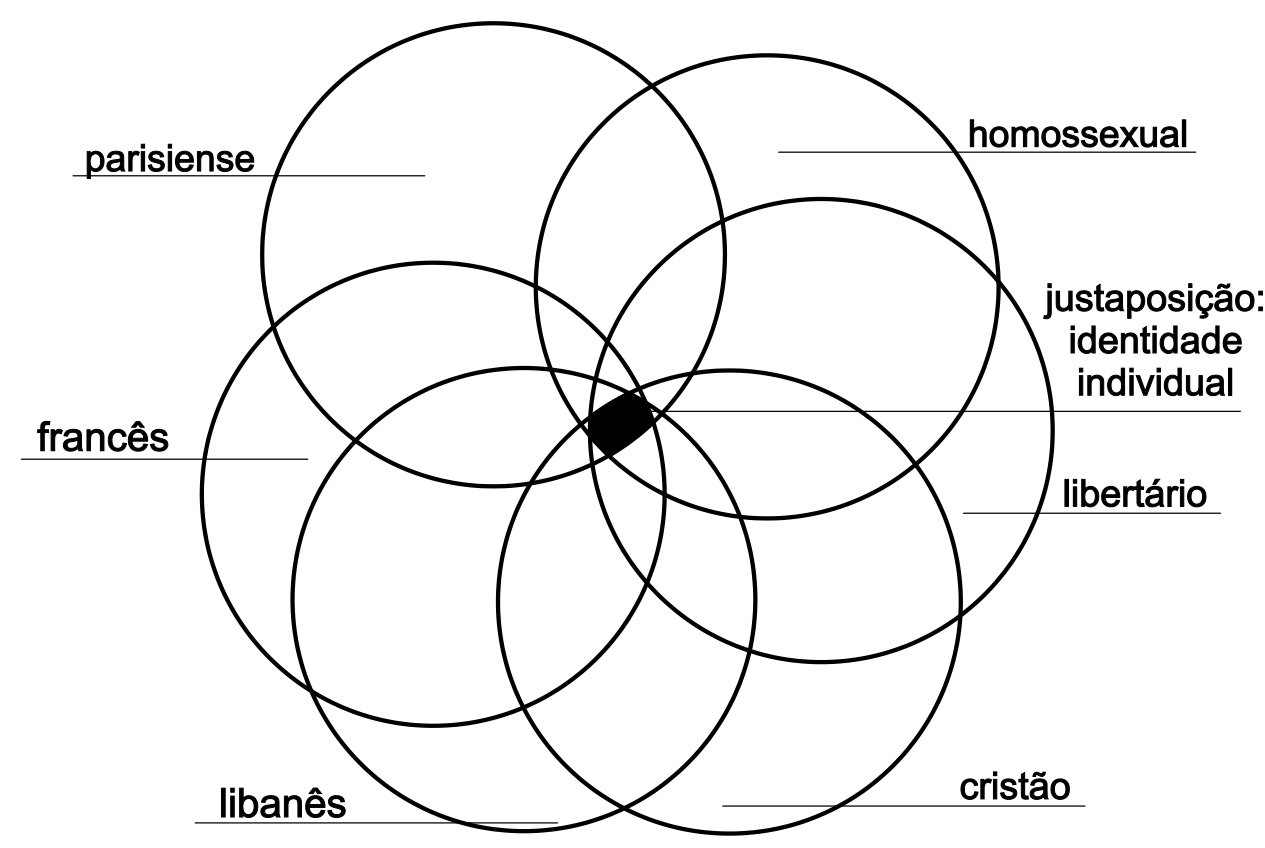

Figura 5 - Exemplo de redes identitárias coletivas formando, em sua justaposição, a identidade individual. (Elaboração própria)

Outra característica importante da identidade na contemporaneidade é que ela está em constante mutação: é fluida e flexível, cambiando conforme as preferências e modificações cognitivas e interpretativas do indivíduo. Assim,

[a]s identidades parecem fixas e sólidas apenas quando vistas de relance, de fora. A eventual solidez que podem ter quando contempladas de dentro da própria experiência biográfica parece frágil, vulnerável e constantemente dilacerada por forças que expõem sua fluidez e por contracorrentes que ameaçam fazê-la em pedaços e desmanchar qualquer forma que possa ter adquirido (Bauman, 2000: 98)

A fluidez identitária deriva essencialmente de duas situações que possibilitam mudanças quanto à escolha identitária individual. Inicialmente, conforme elucidado por 
Badie (1995), existem novas possibilidades identitárias disponíveis para os indivíduos, vez que

O efeito convergente da mundialização e do progresso tecnológico confere aos atores sociais uma mobilidade incessantemente mais afirmada; não somente os emancipa de seu quadro territorial e põe à sua disposição múltiplos recursos, para lhe escapar, como suscita cada vez mais estratégias novas, incitando os indivíduos a transcenderem as fronteiras e a adotarem modos de identificação múltipla e volátil. Outras formas de solidariedade, felizmente numerosas e variadas, impõem-se por si mesmas como relações sociais abertas, capazes de integrar qualquer procedimento voluntário que transcenda os limites territoriais. (Badie, 1995: 156) [...] Acaba mesmo por prolongar toda a interação social simples, construída pela iniciativa individual de todas as pessoas: viagens, trocas, gemeações, estadias de estudo ou de formação no estrangeiro, aprendizagens linguísticas, consumo de bens culturais e midiáticos vindos de outros lados são os átomos de solidariedade extraterritoriais cuja composição têm uma forte propriedade reguladora, frequentemente superior à dos Estados. (Badie, 1995: 269)

Ademais, as solidariedades identitárias perdem intensidade relativa, vez que não há mais qualquer tipo identitário que se sobreponha perenemente e naturalmente sobre todos os outros. Isso é derivado, por um lado, da supracitada ampliação das possibilidades escolhas do mercado de identidades e, por outro, da fluidez identitária característica da Modernidade Líquida. Nesse aspecto, observa-se que

as comunidades vêm em várias cores e tamanhos, mas, se colocados num eixo weberiano que vai de "leve manto" a "gaiola de ferro", aparecerão todas notavelmente mais próximas do primeiro pólo. Na medida em que precisam ser defendidas para sobreviver e apelar para seus próprios membros para que assegurem sua sobrevivência com escolhas individuais e assumam responsabilidade individual por essa sobrevivência - todas as comunidades são postuladas: mais projetos que realidade, alguma coisa que vem depois e não antes da escolha individual (Bauman, 2000: 194)

De tal sorte, é possível entender que as modificações estruturais ocorridas entre os períodos da Modernidade Sólida e da Modernidade Líquida apontam para o sentido de maior liberdade identitária - isto é, da possibilidade de maior escolha individual e situacional das redes identitárias coletivas a qual um indivíduo pertence. Tal assertiva, combinada com as postulações do construtivismo da Teoria do Nacionalismo e o construtivismo social (aqui reformado) da Teoria das Relações Internacionais, permite 
compreender melhor as identidades nacionais como fenômeno das relações internacionais contemporâneas. Esse referencial teórico multidisciplinar, combinado, será importante para observar a multi-identidade no espaço europeu e perceber que as identidades são dinâmicas - construídas, desconstruídas e modificadas a todo o momento pelos indivíduos que, ao mesmo tempo, são por elas influenciadas e a elas constituem intersubjetivamente. 


\section{Identidade e solidariedade na Europa: revisando a história recente e delimitando os desafios à multi-identidade}

Este capítulo tem por objetivo fazer uma análise qualitativa da construção da multiidentidade no espaço europeu. Inicialmente, será feita uma revisão da história jurídicoinstitucional da UE, buscando analisar como determinados instrumentos institucionais pretendem refletir na realidade a existência da Europa como comunidade imaginada e observar que determinados espaços políticos constituídos em termos europeus são elementos refletivos de identidade europeia. Posteriormente, serão enfrentados determinados desafios ao conceito de multi-identidade - especialmente no caso da xenofobia - de modo a elucidar que a Europa, como construção social dinâmica, convive com discursos políticos que objetivam ofertar tipos identitários que favoreçam determinados interesses.

\subsection{Uma história jurídico-institucional: cidadania, identidade e liberdade na UE}

A história recente da UE pode ser remontada pelo tratamento jurídico dado às questões identitárias - e referentes à cidadania - em um passado recente. Inicialmente, é possível compreender que as peças jurídicas que regulavam o espaço europeu sempre tentaram reforçar a ideia de complementariedade entre signos de identificação nacional ou europeu e a construção de espaços políticos que fossem transversais. Posteriormente, é preciso tratar da evolução dos signos próprios à UE - tais como a bandeira, o hino e sua moeda - que garantem algum grau de existência objetiva da União. Finalmente, é necessário tratar das evoluções institucionais necessárias à acomodação da existência da multi-identidade na Europa.

Ainda em 1973 seria exarada pelos nove membros que então formavam as Comunidades Europeias uma Declaração sobre Identidade Europeia, que afirmava:

\footnotetext{
Sharing as they do the same attitudes to life, based on a determination to build a society which measures up to the needs of the individual, they are determined to defend the principles of representative democracy, of the rule of law, of social justice — which is the ultimate goal of economic progress - and of respect for human rights. All of these are fundamental elements of the European Identity.
} 
O Critério de Copenhagen (1993) ${ }^{19}$ sobre as condições necessárias ao acesso de qualquer candidato à UE move-se no mesmo sentido:

\begin{abstract}
Membership requires that the candidate country has achieved stability of institutions guaranteeing democracy, the rule of law, human rights and respect for and protection of minorities, the existence of a functioning market economy as well as the capacity to cope with competitive pressure and market forces within the Union.
\end{abstract}

Torna-se patente, portanto, que os fundamentos da identidade europeia são traçados juridicamente em termos de segurança de direitos. Respeito às minorias e aos direitos humanos; à justiça social; ao direito de propriedade, à liberdade e ao desenvolvimento (por meio da existência de democracias de mercado) são, em última instância, critérios que visam definir objetivos determinados em termos de direitos individuais.

Tal cenário, baseado em modelo referente a democracias liberais, dá esperada prevalência à escolha e a direitos individuais - a despeito de todas as relativizações necessárias quanto ao conflito de uma Europa mais interventista e outra mais liberal (v., p.ex., as críticas heterodoxas de Preece, 2009). Essa configuração é também um reflexo das modificações na realidade social ocidental - e, particularmente, europeia - que tornaria possível a modificação estrutural na construção identitária tal como descrita por Bauman (2000; 2001) e relatada no último capítulo.

Juridicamente, essa cena seria consolidada pela criação do conceito de Cidadania da União Europeia (CdUE). Por um lado, é expresso, in verbis, no texto que emendou, em 1992, o Tratado de Maastricht, que a CdUE é complementar à cidadania nacional ${ }^{20}$. Por outro, calca-se a ideia de uma CdUE em duas vertentes: a atribuição de direitos individuais a todos os cidadãos europeus, independentemente de estarem em seu país de origem; e o compartilhamento de valores genéricos comuns - notadamente paz, democracia, direitos humanos e liberdade.

O arcabouço jurídico objetiva, portanto, atingir o cenário que envolve a possibilidade do acúmulo de múltiplas identidades pelos indivíduos. Mesmo Anthony Smith (1992: 56), autor seminal do conceito de nacionalismo étnico, afirma que "at the

\footnotetext{
${ }^{19}$ PRESIDENCY CONCLUSIONS. Copenhagen European Council - 21-22 June 1993. Paragraph 7.A.iii. 20 "Citizenship of the Union is hereby established. Every person holding the nationality of a Member State shall be a citizen of the Union. Citizenship of the Union shall be additional to and not replace national citizenship". Tratado de Maastricht, Artigo 20 (1).
} 
conceptual level, however, the contradiction between a European identity and existing national identities may be more apparent than real", pois

Human beings retain a multiplicity of allegiances in the contemporary world. They have multiple identities. These identifications may reinforce national identity or cross-cut them. [...] Under normal circumstances most human beings can live happily with multiple identifications and enjoy moving between them as the situation requires. (Smith, 1992: 59)

Smith, contudo, afirma existirem limitações a isso no caso europeu, pois a identidade europeia seria mais estreita que as identidades nacionais. Nesse sentido, Smith (1995: 192) pergunta retoricamente: “who will die for Europe?”.

Laura Cram (2009), todavia, afirma que esta é uma concepção errônea da identidade europeia. Ao invés de buscar um europeísmo romântico, como fez Smith, deveria-se entender a identidade europeia como banal, isto é, como algo que é complementar às identidades nacionais. "European integration need not lead to a convergence of national identities or to the development of a homogeneous European Union identity which challenges or competes with national loyalties" (Cram, 2009: 114). Como será abordado com mais ênfase no próximo capítulo, os dados do Eurobarômetro corroboram com essa assertiva, uma vez que em quase todos os anos em que foi realizado o número de indivíduos que afirmam deter algum tipo de identificação com a Europa supera aqueles que dizem não ter qualquer identificação com a Europa (ver Gráfico II). Nesse sentido, Cram afirma que, ao contrário de limitar a identidade nacional, o processo de integração regional permitiu o florescimento de diversas identidades nacionais para Estados multinacionais, para minorias nacionais, comunidades extraterritoriais e territórios $\operatorname{divididos}^{21}$.

Na mesma linha, Lars-Erik Cederman (2000) afirma que o processo de integração regional, e mesmo a formação de uma identidade europeia, não implica na superação ou supressão de identidades nacionais. Uma vez que a integração europeia não é um tipo puro de estrutura supranacional, existem determinados elementos que ficam a cargo dos Estados e das regiões. Para Cederman (2000: 22-23), os dois elementos mais

\footnotetext{
${ }^{21}$ É interessante exemplo desta situação a postura dos bascos do Ezker Abertzalea (Esquerda Aberta), braço político do grupo terrorista ETA que, embora nunca tenha desejado participar das eleições espanholas, já participou de eleições europeias e afirma em sua última convenção: "Somos un Pueblo europeo, y dentro del proceso de construcción que vive actualmente Europa, debemos definer nuestra arquitectura democrática aprovechando el derecho y la posibilidad que tiene Euskal Herria para un desarrollo democrático propio". (POR UNA NUEVA EUSKAL HERRIA, disponível em: http://www.ezkerabertzalea.info/doku/eskaintza/MarkoDemokratikorakoProposamena-cas.pdf).
} 
importantes para a sustentação de identidades nacionais, como a educação básica e as mídias de massa, dificilmente deixarão de fazer parte do escopo nacional.

De fato, a maior parte dos instrumentos de socialização que influenciam exogenamente a identidade permanecem sob administração de governos nacionais ou locais. Ao contrário de representar uma possível ameaça às identidades nacionais, essa situação significa que a intensidade das identidades europeias, menos reificada e internalizada por indivíduos, torna-se fragilizada. Esse contexto levou o Risse (2010: 134) a caracterizar os métodos de identificação europeia como "identity lite".

Isso não significa que não existam mecanismos institucionais no sentido de tornar mais palpável a comunidade imaginada europeia. Tais mecanismos são, portanto, evidências empíricas de elementos indutivos de identidade europeia - ou seja, elementos que objetivam induzir alguma identidade europeia. Entretanto, todos os movimentos nesse sentido são tomados de modo a tentar reforçar a complementariedade entre os dois tipos identitários.

The European flag with the twelve yellow stars against a dark blue background is now ubiquitous in Europe. The same holds true for the burgundy red European passport, for the European driver's licence, and for licence plates with the EU symbol on it. Europe has its own anthem, Beethoven's "Ode to Joy". Then, of course, there is the European currency, the euro. For each of these identity markers, the message conveyed is the same: Europe and the EU are not constructed in opposition to, but are complementary to, national identities. When Europeans see the EU flag on their evening news, it usually flies alongside the respective national flags. The European passport has both the inscription "European Union" and the respective nation-state. Even the euro has a conscious effort to construct dual identities. (Risse, 2010: 57-58)

Adicionalmente, novos espaços e dinâmicas institucionais na UE acabam por reforçar a supracitada dualidade. O exemplo mais evidente é o Comitê das Regiões da União Europeia, que congrega unidades subestatais e tenta solucionar mais objetivamente os problemas locais e regionais, abandonando a ideia de serem Estados unitários. Como existem regiões com níveis distintos de desenvolvimento econômicosocial dentro do mesmo Estado-Nação, o Comitê das Regiões procura atender tais demandas locais, por meio da alocação de verbas diretamente junto a governos locais ${ }^{22}$.

${ }^{22} \mathrm{O}$ exemplo mais explicativo do impacto do Comitê das Regiões é sua atuação na Suécia. Embora a Suécia, tomada como um todo, esteja muito acima dos níveis de renda per capita médios da União, 
Afora isso, o barateamento de comunicação e transporte dentro da UE (decorrente da integração dos mercados de bens, serviços e capitais e o consequente aumento da concorrência) bem como o abandono de barreiras legais à mobilidade dentro da área Schengen ${ }^{23}$, facilitou o surgimento de redes europeias, tanto transgovernamentais, quanto da sociedade civil organizada. Entre aquelas de maior destaque podem ser citadas, a título de exemplo: European Network Against Racism (http://www.enareu.org/); European Network for Science Centres and Museums (http://www.ecsite.eu/); European Network for Smoking and Tobacco Prevention (http://www.ensp.org/); Network of the Heads of Environment Protection Agencies (http://epanet.ew.eea.europa.eu/); e European Network of Migrant Women (http://www.migrantwomennetwork.org/).

Mesmo grupos que pretendem contestar a dinâmica liberalizante da UE, tal como o Fórum Social Europeu, variante regional do Fórum Social Mundial, são constituídos em termos europeus (e, muitas vezes, em termos da UE, debatendo como solucionar problemas sociais dentro da União). Com isso, torna-se limitado o escopo de contestação - uma vez que a própria existência dessas redes acaba por reforçar um tipo específico de identidade europeia em sua área de atuação.

Exemplo mais excêntrico desse fenômeno, trazido a tona por Hobsbawm (2007: 9296), é o futebol europeu. Desde o julgamento do Caso Bosman na Corte Europeia de Justiça, que determinou que as restrições quanto ao máximo de jogadores estrangeiros nos clubes violava os direitos de mobilidade laboral europeia, os grandes clubes tornaram-se cada vez mais europeizados. Do mesmo modo, os campeonatos se desnacionalizaram em larga escala, dando-se prioridade, cada vez mais, às valorizadas copas continentais. Torcedores de grandes clubes europeus também se desnacionalizaram - espalhando-se pelo continente (e, na verdade, por todo o mundo).

Tanto as redes da sociedade civil e de burocracias europeias quanto o futebol europeu são exemplos empíricos distintos de elementos refletivos de identidade(s)

quando divida em regiões evidencia-se que o Norte sueco - gélido, pouco povoado e pouco produtivo contrasta imensamente com o resto do país. Obtendo esse novo diagnóstico, o Comitê aloca verbas para investimento social no Norte da Suécia. O mesmo ocorre com o Leste alemão, devido às discrepâncias em renda e desenvolvimento herdada pela região do período de planejamento soviético.

${ }_{23}$ "The Schengen area represents a territory where the free movement of persons is guaranteed. The signatory states to the agreement have abolished all internal borders in lieu of a single external border. Here common rules and procedures are applied with regard to visas for short stays, asylum requests and border controls. Simultaneously, to guarantee security within the Schengen area, cooperation and coordination between police services and judicial authorities have been stepped up." (Website da Comissão Europeia). 
europeia(s) - ou seja, elementos que refletem algum tipo identitário já institucionalizado coletivamente - e evidenciam o surgimento de espaços públicos europeus. Em espaços mais oficiais, o Parlamento Europeu também espelha a organização em formato de rede desnacionalizada exemplificado pelas redes transgovernamentais e da sociedade civil. Nele, os Membros do Parlamento Europeu (MPE) se organizam em grupos políticos com base em afinidade político-ideológica não com base em nacionalidade. Conservadores britânicos, eleitos para o PE, aliam-se não a seus rivais trabalhistas, embora britânicos, mas aos liberais alemães - que deles se aproximam ideologicamente.

Como resposta ao surgimento desses novos espaços, foram desenvolvidos argumentos teóricos que procuram englobar essas novas situações. A ideia de "multilevel governance" pressupõe que "the boundaries between national policy making and European policy making have been blurred to the point of insignificance" (Cini \& Borragán, 2010: 115) ${ }^{24}$. Nesse sentido, a integração europeia seria compreendida com a ampla interação entre níveis local, estatal e supranacional - cada um dos quais apresentando uma dinâmica política própria. Os resultados do processo de integração regional estariam, portanto, nas interações dinâmica entre múltiplos níveis decisórios.

A relevância da UE sobre as dinâmicas políticas nacionais torna-se evidente quando se observa que, para uma grande parte dos países, políticas monetária, agrícola, trabalhista, dentre outras, são reguladas desde Bruxelas. Já a importância dos governos locais, muitas vezes ignorada, torna-se mais claro quando percebe-se que $70 \%$ do investimento público na Europa é empreendido por governos locais (OCDE, 2010).

Nesse sentido, o espaço europeu tem caminhado para um unidade (pluralidade?) política que envolve uma multiplicidade de arranjos decisórios em múltiplos níveis. Do mesmo modo, os instrumentos institucionais e as condicionantes legais e infraestruturais para a disseminação de múltiplas identidades europeias criam possibilidades para tornar realidade os modelos filosóficos e teóricos tratados no primeiro capítulo. Isso significa que existem sólidas evidências quanto a convivência de múltiplas identidades e solidariedades, todas elas situacionais, articuladas em nível europeu - mesmo que com o objetivo de defender interesses locais (como é o caso das redes transgovernamentais e da sociedade civil) ou mesmo nacionais - como será observado na próxima seção.

\footnotetext{
${ }^{24}$ Kohler-Koch (1997) vai além, ao falar de uma "Network of European Politics", isto é, a dehierarquização da política europeia.
} 


\subsection{Conflitos e discursos: os desafios à Europa multi-identitária}

Se existe a possibilidade de multi-identidade social variante em termos situacionais, sem que haja necessária rivalidade entre os tipos identitários, como explicar os aparentes conflitos a esta lógica? Tais conflitos seriam representados, por exemplo, pela rejeição do Tratado Constitucional por franceses e holandeses e diversos casos relatados de xenofobia e racismo.

Por óbvio, não se pretende dar aqui uma resposta definitiva à estas questões. O escopo da presente pesquisa é muito mais restrito: qual seja, o de tentar explicar a influência de identidades nacionais, compreendidas genericamente, sobre a integração regional europeia - também compreendida de forma genérica. Entretanto, a ausência do enfrentamento de algumas dessas questões pode constituir uma lacuna imperdoável a qualquer esforço de compreensão sobre identidades nacionais na Europa contemporânea. De tal sorte, essas questões serão abordadas - embora, admoesta-se, somente tangencialmente e de forma precária.

Apoio a percepções genéricas não implicam, necessariamente, ao apoio automático a decisões específicas que se localizem dentro da categoria genérica. Isto é, um indivíduo pode apoiar a integração regional e, ainda assim, por interesses específicos, rejeitar um avanço em determinado sentido. Irlandeses podem se sentir satisfeitos com a UE (como sentem, em sua maioria, segundo demonstram as pesquisas de opinião pública) e ainda assim rejeitarem o Tratado de Lisboa $^{25}$ por causa de uma miríade de questões específicas (como o fizeram em junho de 2008). Neste caso, foram usados como argumentos antirratificação: o uso comum por todos os membros da UE dos recursos haliêuticos na plataforma continental irlandesa e argumentos religiosos, como a ausência da menção a Deus no texto ou a possibilidade de modificação das leis irlandesas sobre o aborto.

\footnotetext{
${ }^{25}$ O Tratado de Lisboa, filho mais modesto do abandonado Tratado Constitucional, é definido pela UE nos seguintes termos: "O Tratado de Lisboa, que entrou em vigor em 1 de Dezembro de 2009, confere à União Europeia instituições modernas e métodos de trabalho eficientes que lhe permitirão dar uma resposta efectiva aos desafios actuais. Num mundo em rápida mutação, os europeus contam com a União Europeia para tratar de questões como a globalização, as alterações climáticas, a segurança e a energia. $\mathrm{O}$ Tratado de Lisboa reforça a democracia na União Europeia e a sua capacidade para defender os interesses dos cidadãos europeus no dia-a-dia."
} 
Do mesmo modo, xenofobia, racismo e intolerância religiosa são assuntos extremamente complexos e preocupantes na Europa contemporânea ${ }^{26}$. Não sem motivo, os órgão da UE movimentam-se para exarar legislações que, ao menos no campo normativo, tentem apontar para um caminho contrário à crescente percepção de xenofobia na Europa, tal como a Decisão-quadro relativa à luta contra o racismo e a xenofobia (2008), do Conselho da União Europeia.

Como compreender, portanto, fenômenos como o crescimento de partidos de extrema-direita antiliberal no continente e, mais importante, a disseminada percepção de que a intolerância avança na Europa? Como explicar que países tidos como ilhas de multiculturalismo e tolerância, como a Holanda, venham a ser marcados por histórias de preconceito e descriminação contra holandeses-marroquinos de origem berbermuçulmana após o assassinato do polêmico cineasta e comentarista Theo van $\mathrm{Gogh}^{27}$ fato descrito pelo Washington Times (2004) como um "mini clash of civilizations"?

A resposta parece residir na importância da linguagem para constituição da realidade social. Como recorda Diez (2001: 98-99), “speaking 'Europe' is ... always to participate in a struggle, as much as is practised from within a discursive context. The politics of integration discourse should not be underestimated". Diez (2001: 88-90) vai além, ao afirmar que

speech acts performed by a variety of actors, often with different intentions, not only led to the establishment of a EU citizenship, but also to the reformulation of the concept of citizenship, with consequences for the shape of the Europolity. ... But to phrase it in such radical terms brings to the fore the political relevance of language beyond the concept of rhetoric as means to political ends, and towards a power that rests in discourse itself. This power makes us understand certain problems in certain ways, and pose questions accordingly. It thereby limits the range of alternative policy options, and enables us to take on others. [grifo nosso]

Mesmo com as necessárias ponderações ante discursos pós-modernos "radicais" (segundo as palavras do próprio autor), o texto citado chama a atenção para uma face importante da disputa ideacional/discursiva nos espaços públicos europeus. Identidades,

\footnotetext{
${ }^{26}$ Se o leitor deseja uma análise teórico-metodológica quanto à construção de identidades étnicas reificadas e radicalizadas para o conflito e a violência, ver Fearon \& Laitin (2000).

${ }^{27}$ Para a melhor compreensão dos conflitos religiosos e civilizacionais que afligem a Holanda contemporaneamente e, em especial, a limitação dos padrões de tolerância na atualidade holandesa que se seguiu ao assassinato de Theo van Gogh - mas com a fagulha da esperança de um arrefecimento futuro ver o brilhante ensaio de Ian Buruma (2007).
} 
como construções sociais, são construídas essencialmente por meio da linguagem - isto é, por meio de uma narrativa que explica quem somos "nós" e o que nos tornaria distintos.

A partir desse pressuposto, é possível compreender que elites políticas têm incentivos para ofertar $^{28}$ determinados tipos ideacionais no mercado de identidades a que se referia Bauman $(2000)^{29}$ e, deste modo, influenciar a percepção de indivíduos sobre qual deve ser o material constitutivo delineador de determinado tipo identitário. Deve-se recordar que identidades, nesse contexto, são tidas como construções dinâmicas ("fluidas"/"líquidas", para Bauman) que se modificam constantemente. Checkel \& Katzenstein (2009: 2-3) ajudam a elucidar este ponto:

Politics - specifically, various forms of politicization - are redefining, remaking, and expanding these intersections. Politicization makes issues part of politics, and it involves a number of different actors and processes. Bureaucrats crafting a Europe centered in Brussels and intellectuals theorizing and normatively justifying a new kind of (cosmopolitan) European allegiance, play key roles. Yet, their projects intersect with xenophobic nationalists, [and] anti-globalization Euroskeptics ... Sometimes European identity is a political construction project undertaken by various national or supranational elites. Talking about the construction of identity suggests an engineering view of politics - one that emphasizes purposeful actors and their political choices.

Checkel \& Katzenstein (2009: 11) argumentam existir uma competição entre dois projetos de identidades europeias significativamente diferentes. O primeiro projeto seria a postulação de uma identidade cosmopolita, liberal e "outward-looking" - e teria seu melhor reflexo no texto do Tratado Constitucional e do Tratado de Lisboa. Seu concorrente seria um projeto de identidade europeia nacionalista-populista focado nas ameaças culturais e econômicas retratadas em figuras caricatas como o temor ao plombier polonais (encanador polonês) ${ }^{30}$ ou ao véu islâmico em espaços públicos.

Cosmopolitan European identities are shaped in part by the liberalization of national markets in the wake of the Single European Act (1987) and the process of market opening in an era of globalization. ... Beyond these economic sources of cosmopolitan and populist, however, Europe also shapes

\footnotetext{
${ }^{28}$ Sou grato às discussões com Raduan van Velthem Meira sobre oferta e demanda no mercado de identidades que me propiciaram uma melhor compreensão dessas dinâmicas.

${ }^{29}$ Ver Capítulo anterior

30 "The "Polish plumber" - a symbol of cheap labour - became a catchphrase of the French "No" camp during the referendum on the EU constitution." (BBC, 2005)
} 
enduring senses of loyalty and obligation, linking the individual to the community. In contrast to the nation, dying for Europe is not a political litmus test; not killing Europeans is. ... Populist conceptions of European identities have cultural and ethnic rather than political content. The political and social integration of ethnic and cultural minorities is a task that populist conceptions of European identities regard as a threat. "Europe for Europeans" rallies the supporters of an illiberal political project. (Ibidem: 12)

De fato, há um sensível crescimento da extrema direita em países como Holanda, Dinamarca, Suécia e, especialmente, Áustria. Mas esses fato podem ser enganosos se lidos fora de contexto. Pesquisas recentes mostram que os dados quanto ao racismo e xenofobia são ambíguos - países que indicam maiores índices de racismo também demonstram maior disposição da população para que governos adotem estratégias de integração e assimilação (em oposição à segregação) por parte de seu governo (Eurobarômetro especial sobre racismo e xenofobia, $\left.\mathrm{n}^{\circ} 47.1,1997\right)$. Muitas vezes, a maior motivação para intolerância não é propriamente cultural - embora esses elementos sejam claramente explorados no discurso político -, mas quanto a uma insatisfação com a corrente situação política nacional e com o fardo fiscal decorrente de um peso tido como "excessivo" sobre os mecanismos de bem estar social por cidadãos nacionais descendentes de imigrantes ${ }^{31}$.

Nesse sentido, nota-se que os conflitos existentes na Europa estão inseridos em um contexto de politização das identidades. Isso significa que esses conflitos são caracterizados pela disputa entre elites políticas que postulam tipos identitários que facilitam o atingimento de determinados interesses objetivos e subjetivos. Esse processo é dinâmico e seu resultado ainda está em aberto.

A julgar pelo passado recente, embora as lideranças xenófobas apresentem crescimento importante em determinados países, elas ainda estão longe de conseguir uma maioria nacional. Até o momento, aparentemente, para a maioria dos europeus ganhos objetivos com a integração parece superar os discursos antiliberais e xenófobos

\footnotetext{
${ }^{31}$ A leitura dos diversos comentários feitos por cidadão austríacos no sítio da BBC, quando este reportava o avanço eleitoral da extrema direita austríaca, é uma experiência quase etnográfica (pois é uma observação não-participante) e nos dá acesso a percepções únicas que estão via de regra ausentes das análises políticas sobre a situação. A título de exemplo, vale observar essa opinião: "This is a horrific result but it was obvious that this was going to happen. Here is my attempt to explain this result: Austrians in general are not "right-friendly" at all. It was a vote to show the two major parties (social democrats and the conservatives) that they didn't do a very good job in the past two years. I think Austrians are shocked with the result and some actually don't even feel safe there anymore. It is terrible what bad politicians can do to a great country. Stefan Herovitsch, Soll, Tirol, Austria". Para outros exemplos, visitar: http://news.bbc.co.uk/2/hi/europe/7641441.stm
} 
- embora, em casos com a candidatura turca à UE, discursos de intolerância cultural e perdas objetivas se misturem. O resultado final dependerá, portanto, das escolhas das diversas populações europeias - elas serão o fiel da balança dessa disputa entre elites.

Essa leitura ajuda a compreender que os potenciais desafios à multi-identidades europeias não devem ser tomados como fatos dados ou condicionantes objetivas. É preciso problematizar tais desafios e tomá-los de forma contextualizada, de modo a não superestimá-los ou entendê-los como barreiras impenetráveis. Outrossim, não se deve tomar uma postulação identitária de elites políticas e tomá-la como realidade, descolando a oferta de identidades pela demanda de identidades - ou a recepção de diversos tipos identitários pelos indivíduos europeus. 


\section{Mensurações e testes quantitativos sobre identidade nacional na Europa}

Este capítulo analisa dados estatístico colhidos e sistematizados pelo Eurobarômetro - um survey multitemático realizado semestralmente há quase quarenta anos pela Comissão Europeia. O capítulo tem como objetivo testar matematicamente os dados existentes para, em conjunto, as análises teórico-qualitativa e quantitativa, resultarem um diagnóstico robusto das relações entre identidades nacionais e integração regional na Europa.

A primeira seção argumenta que a multi-identidade é realidade estatística no espaço europeu. Utilizam-se os dados do Eurobarômetro para o delineamento de dois índices. O índice de Identidade Europeia Líquida, adaptado de Risse (2010), demonstra que de fato há preponderância da multi-identidade na Europa, com a maioria dos cidadãos identificando-se tanto com sua nação, quanto com a Europa. Já o Índice Ponderado de Identidade, elaborado pelo autor, pretende demonstrar que há prevalência da identidade nacional - e que, portanto, apesar de existir multi-identidade, a expressão das identidades nacionais não está em perigo.

Por sua parte, a segunda seção enfoca-se no isolamento da identidade nacional como variável para testar sua influência sobre a integração regional. Depois desse isolamento, são feitos três testes estatísticos independentes que apontam para inexistência de impacto negativo das identidades nacionais sobre a percepção individual quanto à integração regional na Europa.

\subsection{Multi-identidade como realidade estatística no espaço europeu}

É recorrente na literatura sobre integração regional a ideia de ser uma identidade europeia impossível, uma vez que a pluralidade linguística no continente e a persistente nacionalização das mídias não permitiriam a formação de um demos europeu (v. Gabel \& Anderson, 2001). Inexistiriam, portanto, espaços públicos que propiciassem a necessária interação entre indivíduos para que possa surgir uma identidade comum. 
Entretanto, ao serem analisados os índices do Eurobarômentro, observa-se que a maioria dos europeus, durante a maior parte da história recente, afirma ter algum grau de identificação com a Europa. Como já visto, as identidades europeias são postuladas em termos complementares às identidades nacionais. Tal postulação parece se refletir nos dados coletados historicamente pelo Eurobarômentro. O Gráfico I corrobora para essa assertiva, uma vez que os respondentes que afirmam deter algum tipo de identidade europeia (na grande maioria dos casos, somadas às identidades nacionais) são predominantes.

Com esses dados em mãos - de modo a tornar essa situação mais evidente - é possível derivar um índice de Identidade Europeia Líquida (IEL), nos moldes propostos por Risse (2010). Este índice consistiria no resultado da subtração da porcentagem de respondentes que afirma não deter nenhum grau de identidade europeia do total de respondentes que afirma deter algum grau de identificação com a Europa. Se o resultado for positivo, significa que, naquela medição, houve prevalência de multiidentidade no espaço europeu.

$$
I E L=i e-n e
$$

\section{Em que:}

IEL é o Identidade Europeia Líquida

$\underline{i e}$ é o percentual de respondentes que afirmam ter algum grau de identificação com a Europa;

$\underline{n e}$ é o percentual de respondentes que afirmam não deter nenhum grau de identidade europeia do total.

De posse dos dados e da ideia de IEL, é possível verificar a variação e tendências na série histórica europeia, conforme observável no Gráfico II. Percebe-se, neste caso, que há uma tendência positiva quanto à IEL, muito embora o desvio padrão médio (e também a variância dos últimos anos) seja relativamente alto.

Ademais, é possível verificar que existe uma grande variância entre distintos membros da UE quanto à percepção identitária. Enquanto países ibéricos e da Europa central possuem IEL positiva, segundo a última pesquisa do Eurobarômetro, Bélgica, países do Leste europeu e, especialmente, o Reino Unido têm baixa identificação europeia, conforme observável no Gráfico III. Esse dado é de extrema relevância, uma 
vez que, embora seja possível verificar a realidade estatística da multi-identidade no espaço europeu tomado como um todo, para maior precisão de futuros estudos é necessário considerar as particularidades de cada região.

Afora isso, é importante enfatizar que, em termos de intensidade, as identidades nacionais retêm seu papel preponderante como comunidade imaginada mais relevante no espaço europeu. $\mathrm{O}$ índice de IEL não considera as intensidades das identidades. Entretanto, é possível calcular essa relação com a mesma base dados, por meio da formulação de um Índice Ponderado de Identidade (IPI).

Tal índice pode ser obtido através da atribuição de pesos distintos para cada uma das respostas lançadas pelo Eurobarômetro. Os surveys fazem a seguinte pergunta: "Hoje ou em um futuro próximo, você se sente: (a) SOMENTE NACIONAL; (b) NACIONAL E EUROPEU; (c) EUROPEU E NACIONAL; ou (d) SOMENTE EUROPEU. Para formular índices ponderados de identidade europeia (IPIe) e nacional (IPIn), pode-se tomar as seguintes equações, que renderá um resultado em uma escala de zero a 300 , expressos em uma análise cross-country no Gráfico IV:

$$
\begin{aligned}
& \text { IPIe }=100(0 a+1 b+2 c+3 d) \\
& \text { IPIn }=100(3 a+2 b+1 c+0 d)
\end{aligned}
$$

\section{Em que:}

IPIe é o Índice Ponderado de Identidade Europeia; $e$

IPIn é o Índice Ponderado de Identidade Nacional; $e$

(a), (b), (c) e (d) equivalem às porcentagens obtidas como resposta à questão do Eurobarômetro proposta acima 


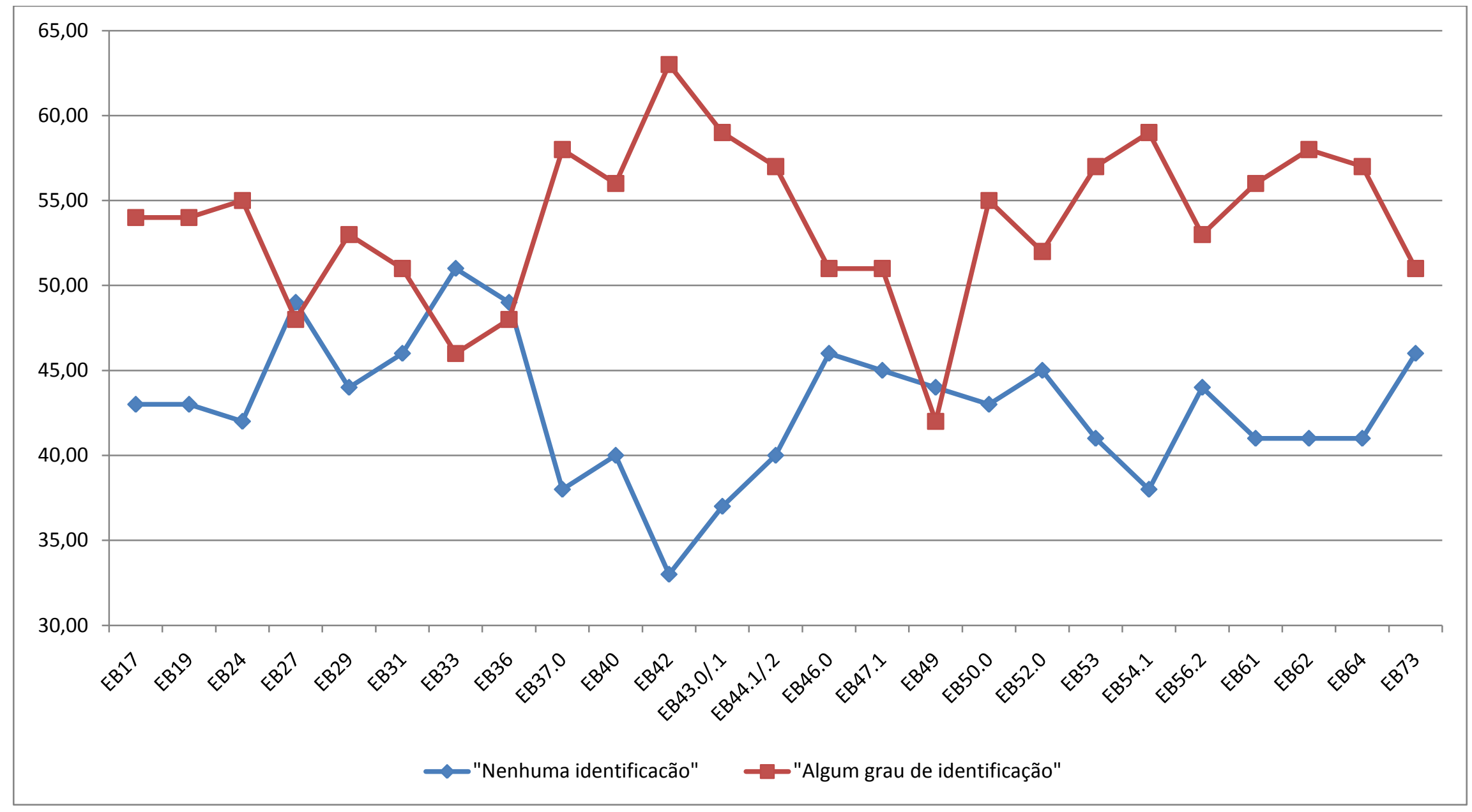

Gráfico I - Algum grau de identificação vs. Nenhum grau de identificação com a Europa. 


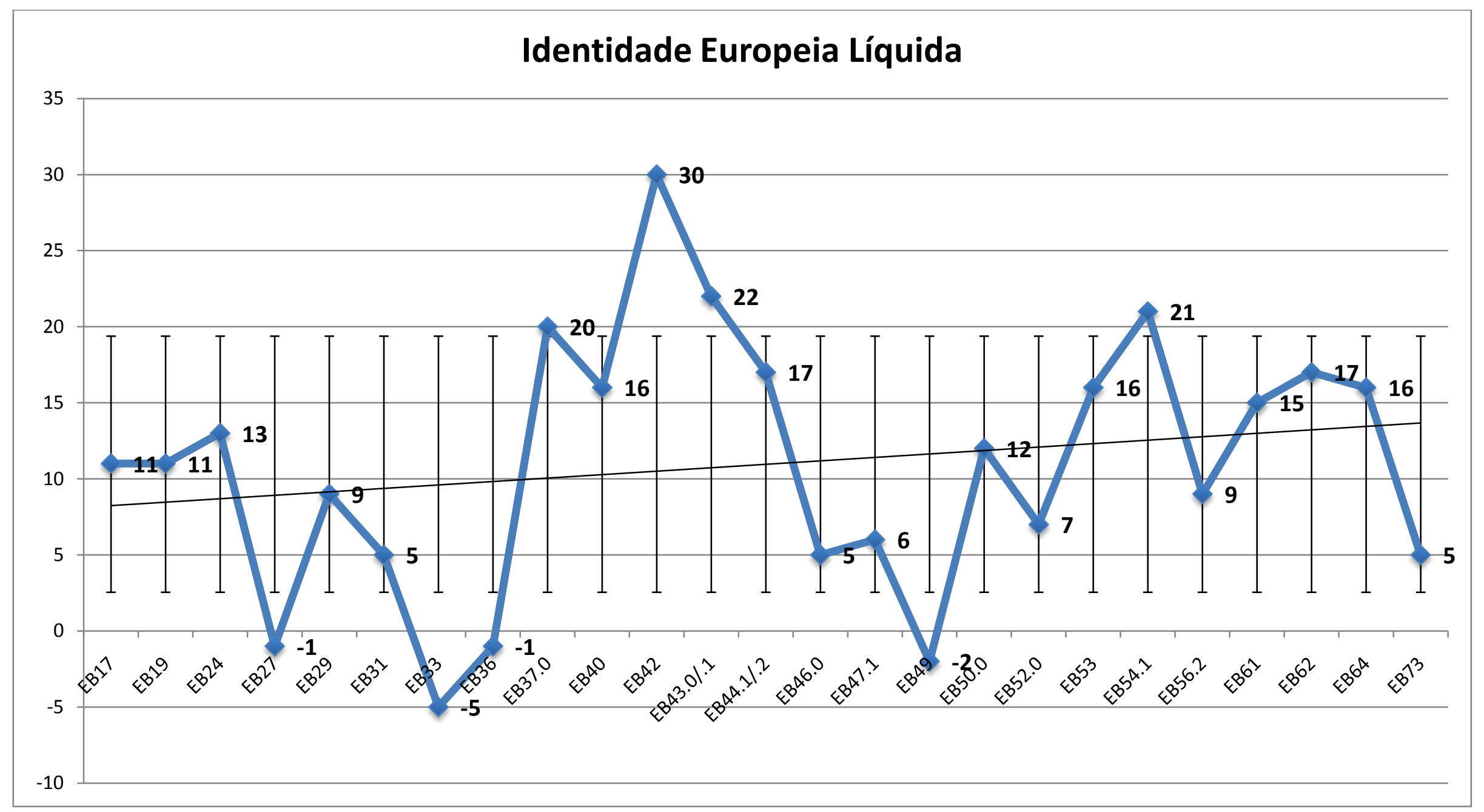

Gráfico II - Identidade Europeia Líquida, calculada da seguinte maneira: (Respondentes que afirmam ter algum grau de

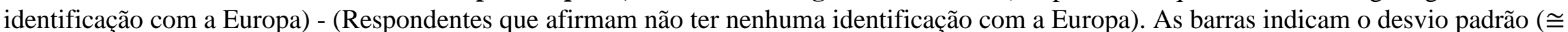
$8,41)$ a partir da média da série $(\cong 10,96 \%)$. Conceito e método elaborado por Risse (2010), mas adaptado e ampliado neste trabalho 


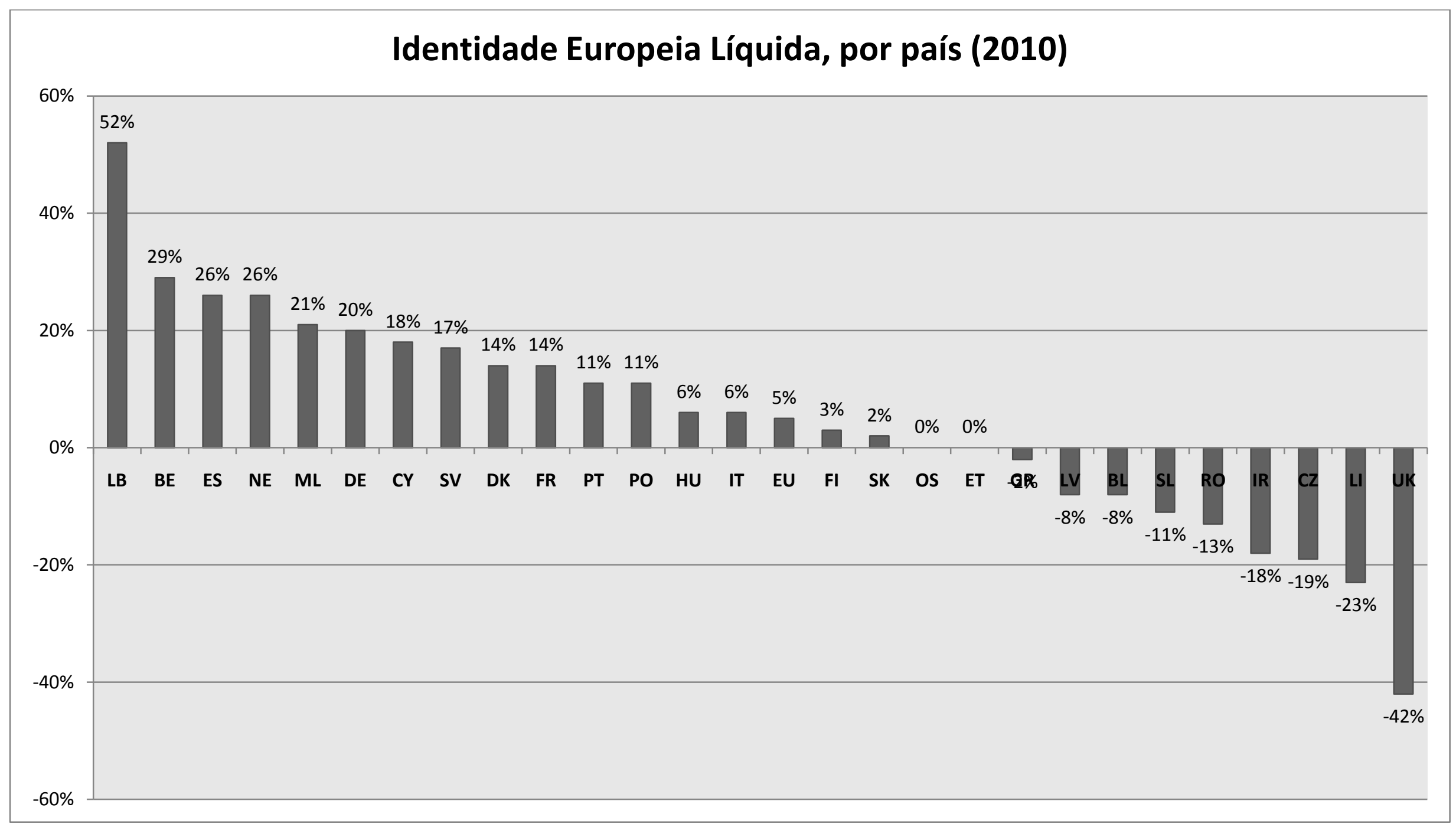

Gráfico III - Identidade Europeia Líquida, por país, Eurobarômetro 73 (2010). 


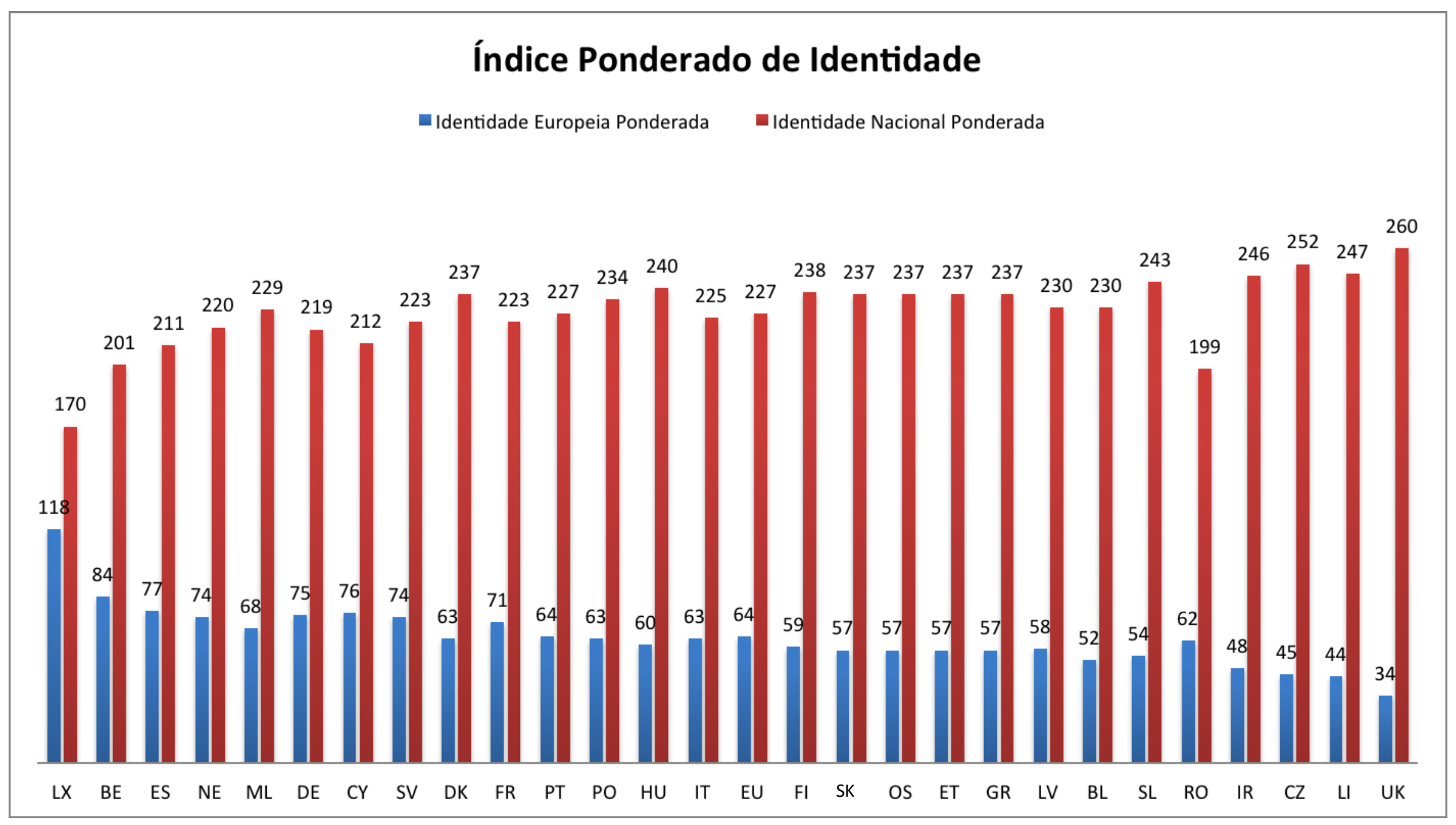

Gráfico IV - Índice Ponderado de Identidade. Eurobarômetro 73, 2010. 
Como assinala Cederman (2000), são necessários novos modelos teóricos que consigam abarcar a possibilidade de identidades múltiplas e a conviência do EstadoNação com diversas identidades transnacionais europeias. As críticas que argumentam a impossibilidade de uma identidade europeia focam-se em demasia em uma perspectiva primordialista da identidade nacional. Por outra parte, perspectivas que postulam a superação do Estado-Nação são demasiadamente normativas e guardam pouca relação com a realidade social. Nesse sentido, Cederman (2000) traçou uma matriz para abarcar todas as possibilidades quanto ao futuro da acomodação entre identidades nacionais e europeias, qual seja:

\begin{tabular}{cc|c|} 
Lógica da formação & \multicolumn{2}{c}{ Relação com o Estado-Nação } \\
identitária & Manutenção & Superação \\
\cline { 2 - 3 } Primordialista & Etnonacionalismo & Pan-nacionalismo \\
\cline { 2 - 3 } Construtivista & "Bounded integration" & Pós-nacionalismo \\
\cline { 2 - 3 } & &
\end{tabular}

Tabela 1 - Multi-identidade e Estado-Nação (Cederman, 2000)

Cederman propõe, portanto, que é possível a construção de uma identidade europeia que seja complementar às identidades nacionais em um modelo de "bounded integration" (Cederman, 2000: 20). Este modelo pressupõe um esquema de integração em que convivem identidades nacionais e europeias, com prevalência das primeiras. Tal modelo parece se enquadrar de modo pleno às descobertas empíricas contidas nos dados analisados.

\subsection{Isolando a identidade nacional como variável: testes independentes para verificar possíveis correlações}

Tendo sido estabelecido que a multi-identidade tem comprovação estatística na Europa, faz-se necessário o isolamento da identidade nacional, como variável, para verificar se existe correlação entre uma adesão mais firme (ou exclusivista) às identidades nacionais e uma postura de oposição à integração regional. Será utilizada a mesma série de vinte e cinco surveys conduzidos pelo Eurobarômetro que serviu de base para confirmação estatística da multi-identidade na Europa. 
De posse dos números, foram traçados índices de correlação entre uma variável independente e três grupos independentes de variáveis dependentes de modo a testar a hipótese sob escrutínio. Índices de correlação buscam traçar o grau de correspondência tendencial entre duas séries estatísticas. A correlação é expressa matematicamente em um índice que varia de -1 (que corresponde à correlação negativa plena) a +1 (correspondente à correlação positiva plena). Os índices de correlação foram calculados pela seguinte equação:

$$
R=\frac{n \sum X Y-\sum X \sum Y}{\sqrt{n\left(\sum X^{2}\right)-\left(\sum X\right)^{2}}-\sqrt{n\left(\sum Y^{2}\right)-\left(\sum Y^{2}\right)}}
$$

\section{Em que:}

$\underline{R}$ é o índice de correlação;

$\underline{X}$ é a variável independente; $e$

Y é a variável dependente

O julgamento da hipótese foi feita em duas etapas. Inicialmente, foram traçados os índices de correlação entre a variável independente e os três grupos de variáveis dependentes e foi feita a comparação dos resultados com aqueles que seriam esperados para reforço da hipótese. Neste ponto, é necessária uma nota metodológica.

Existe uma fragilidade na técnica aqui utilizada, pois idealmente deveriam ser agregadas ao teste múltiplas variáveis independentes - sendo uma variável independente principal e outras variáveis de controle. Entretanto, não existiam dados suficientes para comportar o modelo ideal no escopo de uma pesquisa de curto tempo como a presente.

Por outro lado, essa fragilidade é compensada (no mínimo parcialmente) pelo fato de terem sido realizados três testes independentes que corroboraram para o mesmo resultado. Em tese, seria possível que um dos testes apontasse em sentido contrário - o que invalidaria o resultado estatístico ora apresentado.

Entretanto, todos os testes estatísticos apontaram para o mesmo sentido - reforçando mutuamente os resultados apresentados. Nesse sentido, a existência de três testes independentes implica no óbvio fato de que os testes servem de controle entre si. Por esta razão, ainda que seja necessário (e intelectualmente honesto) reconhecer essa 
fragilidade, afirma-se que os resultados apresentados são relevantes em decorrência do controle exercido por três testes independentes e a decorrente segurança dos testes obtidos.

Para a realização dos testes foi inicialmente isolada a variável independente, qual seja, a porcentagem de respondentes que afirmavam ter identificação exclusiva com a nação. Posteriormente, foi traçado o índice de correlação com as seguintes variáveis dependentes (sempre medidos em porcentagem):

(A1) Ser membro da UE é algo BOM;

(A2) Ser membro da UE é algo RUIM;

(B1) Meu país se BENEFICIOU com a UE;

(B2) Meu país NÃO SE BENEFICIOU com a UE;

(C1) O fim da UE seria uma SATISFAÇÃO;

(C2) O fim da UE seria uma LÁSTIMA.

Embora sejam seis variáveis testadas, são somente três testes independentes, uma vez que existe uma relação de inversa proporcionalidade em relação as duas variáveis de cada grupo. Os resultados estão dispostos na Tabela 2 e nos Gráficos V, VI e VII abaixo. 


\begin{tabular}{|c|c|c|c|c|c|c|c|}
\hline - & $\begin{array}{c}\text { Respondente se } \\
\text { identifica de forma } \\
\text { exclusiva com o Estado- } \\
\text { Nação }\end{array}$ & $\begin{array}{c}\text { Ser membro da UE } \\
\text { é algo BOM }\end{array}$ & $\begin{array}{c}\text { Ser membro da UE } \\
\text { é algo RUIM }\end{array}$ & $\begin{array}{c}\text { Meu país se } \\
\text { BENEFICIOU com a } \\
\text { UE }\end{array}$ & $\begin{array}{l}\text { Meu país NÃO SE } \\
\text { BENEFICIOU com a } \\
\text { UE }\end{array}$ & $\begin{array}{l}\text { O fim da UE seria } \\
\text { uma SATISFAÇÃOO }\end{array}$ & $\begin{array}{c}\text { O fim da UE seria } \\
\text { uma LÁSTIMA }\end{array}$ \\
\hline EB17 & 43.00 & 52.00 & 14.00 & - & - & 12.00 & 40.00 \\
\hline EB19 & 43.00 & 54.00 & 13.00 & 52.00 & 25.00 & 9.00 & 41.00 \\
\hline EB24 & 42.00 & 60.00 & 11.00 & 53.00 & 30.00 & 10.00 & 43.00 \\
\hline EB29 & 44.00 & 58.00 & 11.00 & 52.00 & 30.00 & 10.00 & 43.00 \\
\hline EB31 & 46.00 & 64.00 & 8.00 & 55.00 & 28.00 & 8.00 & 45.00 \\
\hline EB33 & 51.00 & 64.00 & 8.00 & 59.00 & 24.00 & 8.00 & 48.00 \\
\hline EB36 & 49.00 & 69.00 & 8.00 & 56.00 & 26.00 & 7.00 & 49.00 \\
\hline EB37.0 & 38.00 & 69.00 & 8.00 & 56.00 & 26.00 & 9.00 & 48.00 \\
\hline EB40 & 40.00 & 60.00 & 12.00 & 47.00 & 35.00 & 11.00 & 40.00 \\
\hline EB43.0/.1 & 37.00 & 58.00 & 12.00 & 46.00 & 33.00 & 13.00 & 39.00 \\
\hline EB44.1/.2 & 40.00 & 54.50 & 12.00 & 48.00 & 32.00 & - & - \\
\hline EB46.0 & 46.00 & 48.00 & 17.00 & 42.00 & 36.00 & - & - \\
\hline EB47.1 & 45.00 & 46.00 & 15.00 & 41.00 & 36.00 & - & - \\
\hline EB49 & 44.00 & 51.00 & 12.00 & 46.00 & 31.00 & - & - \\
\hline EB50.0 & 43.00 & 54.00 & 12.00 & 49.00 & 31.00 & 13.00 & 36.00 \\
\hline EB52.0 & 45.00 & 50.00 & 12.00 & 46.00 & 31.00 & - & - \\
\hline EB53 & 41.00 & 49.00 & 14.00 & 47.00 & 32.00 & - & - \\
\hline EB54.1 & 38.00 & 50.00 & 14.00 & 57.00 & 32.00 & 14.00 & 28.00 \\
\hline EB56.2 & 44.00 & 53.00 & 12.00 & 52.00 & 27.00 & - & - \\
\hline EB61 & 41.00 & 48.00 & 17.00 & 47.00 & 35.00 & - & - \\
\hline EB62 & 41.00 & 56.00 & 13.00 & 53.00 & 34.00 & & \\
\hline EB64 & 41.00 & 50.00 & 15.00 & 52.00 & 36.00 & & \\
\hline EB73 & 46.00 & 49.00 & 18.00 & 53.00 & 35.00 & 13.00 & 39.00 \\
\hline
\end{tabular}

Tabela 2 - Dados Brutos do Eurobarômetro e coeficientes de correlação entre variáveis 


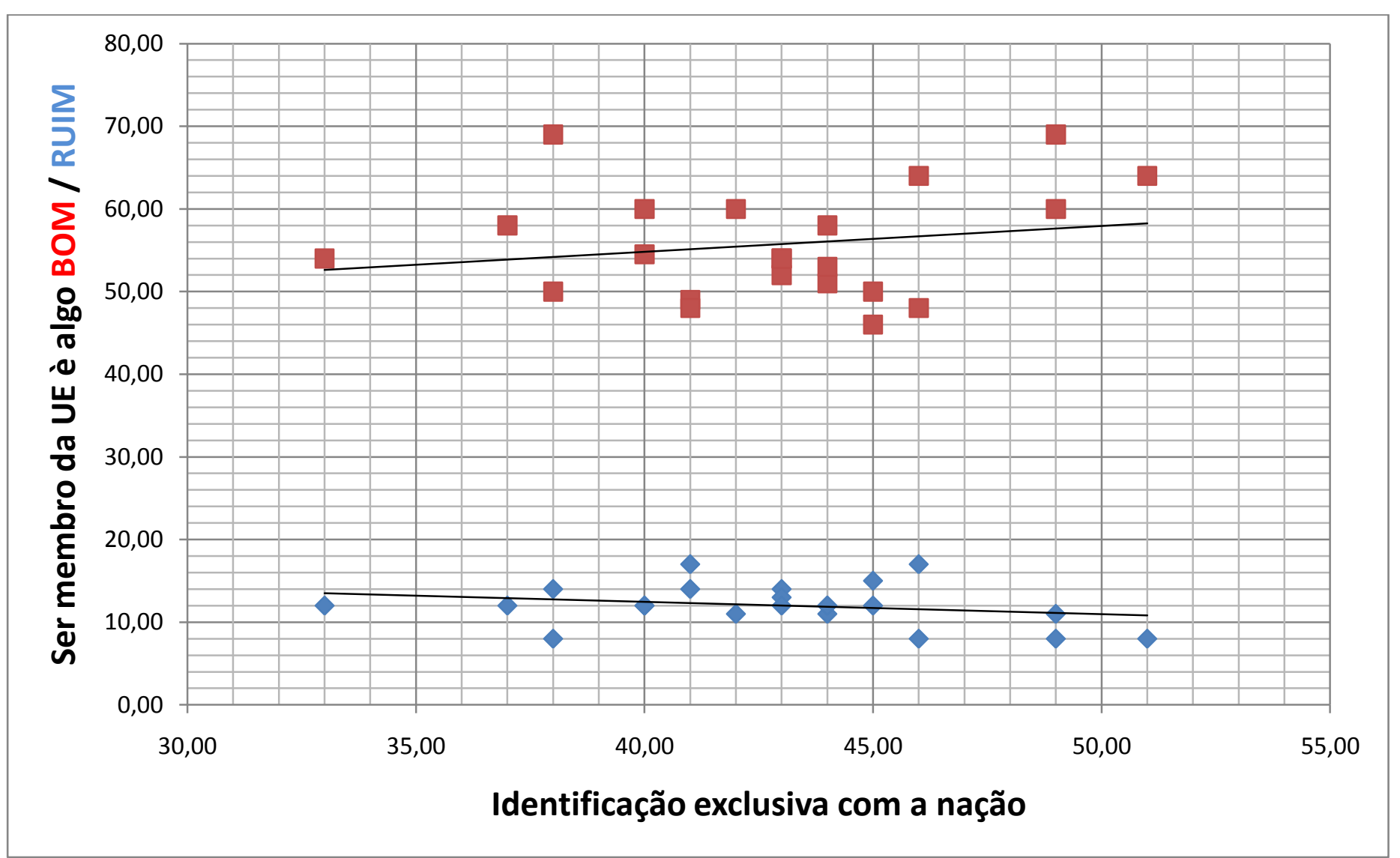

Gráfico V - Percepção sobre a UE para respondentes que têm identificação exclusiva com a nação 


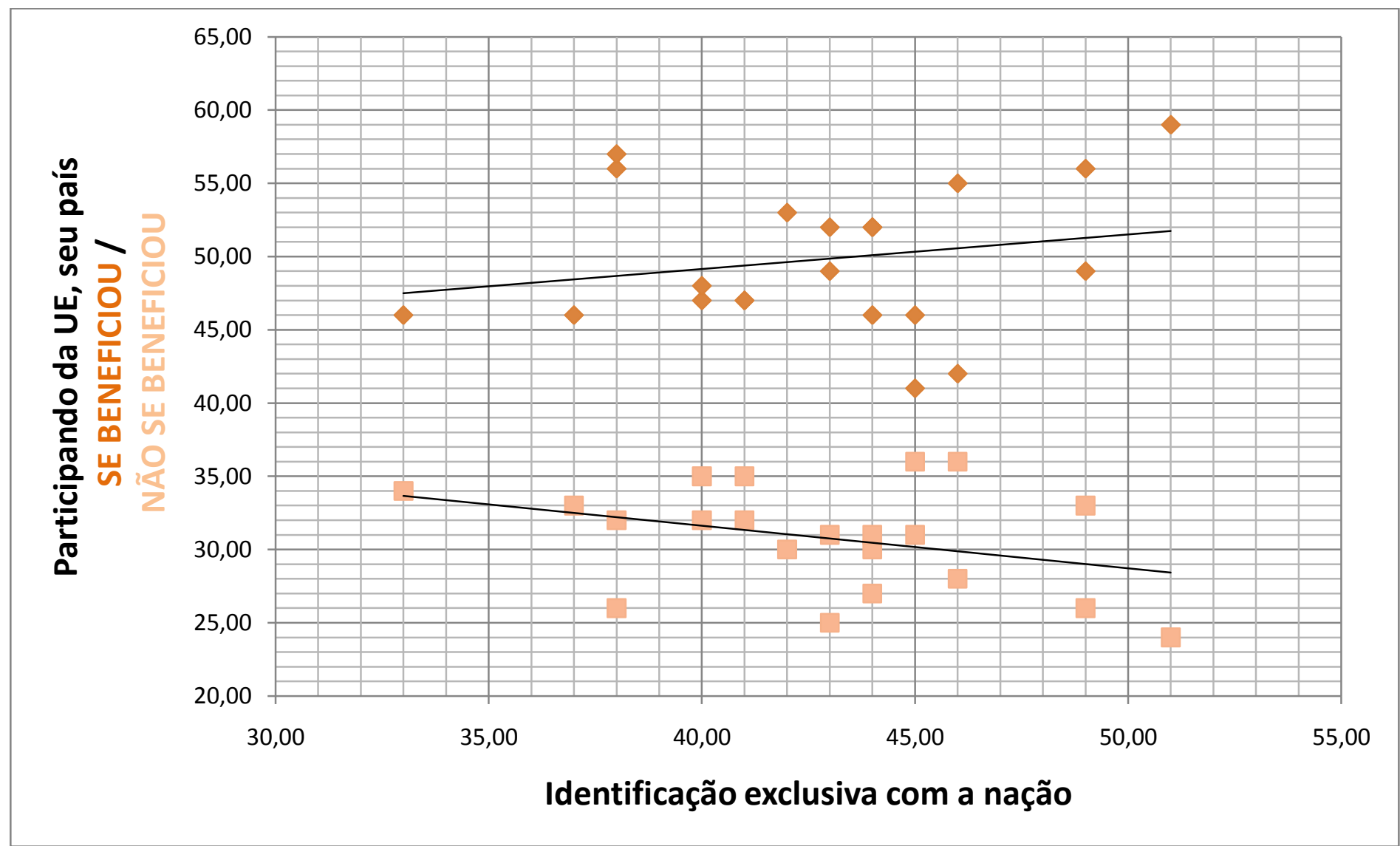

Gráfico VI - Percepção de benefício com a UE para respondentes que têm identificação exclusiva com a nação 


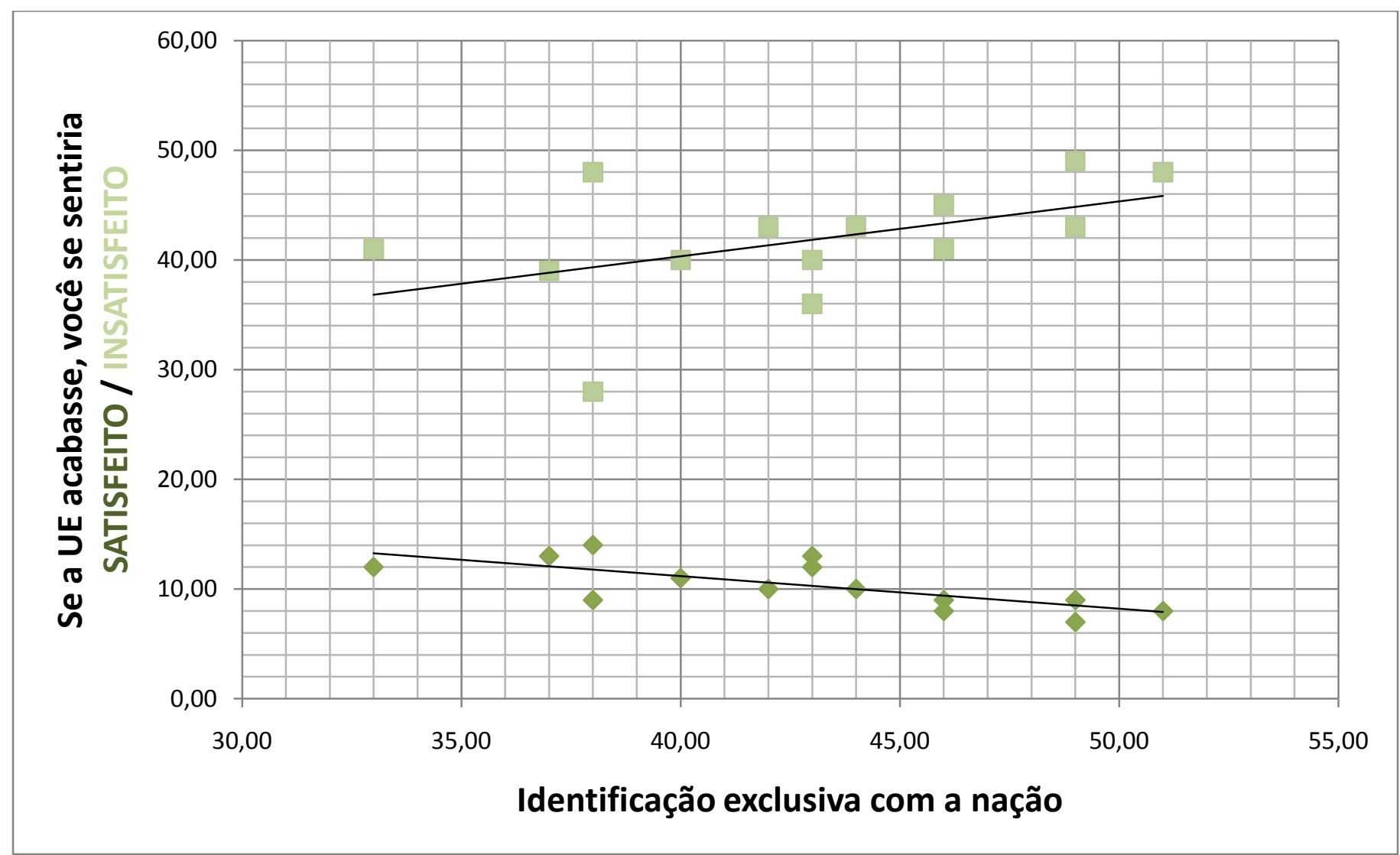

Gráfico VII - Sentimento quanto ao possível fim da UE para respondentes que têm identificação exclusiva com a nação 
Para o reforço da hipótese de serem as identidades nacionais obstáculos à integração regional, seria necessário que os dados indicassem que uma identificação exclusiva com a nação mantivesse correlação positiva com algumas respostas, notadamente: a UE é algo ruim (A2); meu país não se beneficiou com a UE (B2); e o fim da UE seria uma satisfação (C2). Por consequência lógica, a variável independente deveria manter correlação negativa com as respostas: a UE é algo bom (A1); meu país se beneficiou com a UE (B1); e o fim da UE seria uma lástima (C1).

Não obstante, quando traçados os índices de correlação entre as variáveis, acabou-se por ser evidenciada relação oposta daquela esperada para implicar em um reforço da hipótese testada. De fato, ocorre leve correlação negativa com aquelas variáveis dependentes em que era necessária correlação positiva para reforço da hipótese.

A existência de correlação, ainda que leve, em sentido contrário àquele necessário para reforço da hipótese em teste tem grande relevância. A satisfação da correlação esperada não implicaria, necessariamente, causalidade e, em tal caso, seriam necessários outras digressões que pudessem confirmar uma suposta relação de causalidade entre as variáveis. Entretanto, se é comprovada a inexistência sequer de correlação é natural decorrer, como conclusão óbvia, que tampouco pode existir relação de causalidade. Destarte, os resultados empíricos ora testados apontam para negação da hipótese de serem as identidades nacionais obstáculos à integração regional. 


\section{Conclusões}

Este trabalho pretendia contribuir, ainda que de forma limitada, à compreensão de um importante traço das relações internacionais contemporâneas - notadamente a intersecção entre fenômenos usualmente estudados pela Economia Política Internacional e Antropologia/Sociologia: integração regional e identidade nacional e nacionalismo, respectivamente. Para tanto, tinha-se como meta atingir quatro objetivos ao fim da pesquisa: um objetivo de cunho teórico, dois de caráter empírico e um último marcadamente ético.

A face teórica da pesquisa buscou enfatizar que, embora autores aderentes ao construtivismo social tenham tido o mérito de trazer para o centro do debate teórico a problematização de interesses e identidades no estudo das relações internacionais, estruturalismo e estatocentrismo permanecem como obstáculos a serem superados. Ao contrário do que afirma Wendt (1999), o estatocentrismo das TRI não é análogo ao "árvore-centrismo" dos botânicos - pois Estados são ficções jurídicas que não possuem identidades e interesses per se, mas são reflexos dos indivíduos que os constituem e lhe dão uma realidade imaginada - como a literatura sobre identidade nacional nos ajuda a compreender. Existem, portanto, fluxos ideacionais não somente entre governos, mas entre indivíduos de distintas sociedades e entre burocracias estrangeiras e entre partes específicas de burocracias de dois governos diferentes. As identidades de distintos atores são múltiplas e situacionais - e sua existência imaginada influencia a delineação de interesses governamentais, identidades corporativas governamentais e a própria dinâmica identitária dos indivíduos. A superação das barreiras do estruturalismo e estatocentrismo, portanto, constitui passo fundamental para a compreensão de fenômenos como a identidade nacional e pode, potencialmente, contribuir para o entendimento de uma miríade de outros fenômenos - tal como, por exemplo, conflitos étnicos e os genocídios de Ruanda e Iugoslávia. Para tanto é necessário traçar pontes com os autores clássicos e racionalistas de TRI e com disciplinas correlatas das Ciências Sociais. Foi o que se pretendeu fazer no presente texto.

O primeiro objetivo empírico era o de trazer evidências quantitativas e qualitativas para demonstrar a existência subjetiva da multi-identidade no espaço europeu. Indivíduos convivem com múltiplas identidades ao mesmo tempo - e a relevância 
primária de cada uma delas muda conforme o contexto. Ademais, quão maior a possibilidade de escolha individual e liberdade identitária, maior será a possibilidade de convivência pacífica de múltiplas identidades contextualizadas. A existência de múltiplas identidades europeias convivendo com múltiplas identidades nacionais é evidenciada não somente pelos dados estatísticos da série de surveys do Eurobarômetro - que demonstram uma média positiva e tendência de ascensão no índice de Identidade Europeia Líquida - como também pelas expressões objetivas da identidade europeia junto as identidades nacionais, sejam eles indutivos - como o hino ou a bandeira - ou refletivos - como a formação de redes europeias de ação política ou de solidariedade empática.

Já o segundo objetivo empírico era o de restar demonstrada ausência de correlação positiva (e, portanto, ausência de causalidade) entre a existência de identidades nacionais mais arraigadas e uma postura negativa em relação à integração regional. Após três testes independentes com base em dados do Eurobarômetro, observou-se que todos os testes indicam ausência da supracitada correlação. Os dados são extensos e as séries estatísticas longas, o que reforça as conclusões ora apresentadas. Mesmo com a não utilização de regressões multivariáveis, o que conta negativamente para a fidelidade dos resultados, a realização de três testes independentes significam que os resultados dos testes funcionam de controle entre si. A despeito das limitações inerentes à utilização de surveys, a complementação das séries estatísticas com as análises teóricas, filosóficas e históricas das outras seções parece apontar para o mesmo sentido.

Por fim, há uma dimensão ética da presente pesquisa e do falseamento da hipótese de correlação negativa entre identidades nacionais e apoio à integração regional. A hipótese testada tem alta disseminação no discurso político - isto é, é altamente propagada a ideia de serem os processos de integração regional ameaças à identidade nacional de cada sociedade. Nesse aspecto, objetivou-se demonstrar que essas construções discursivas são somente isto: construções. Não existem elementos empíricos e racionais para dar sustentação aos argumentos utilizados por partidos radicais ou xenófobos. Ao contrário, as evidências caminham em sentido oposto. Do mesmo modo, o analista não deve confundir disputas discursivas travadas entre elites políticas com aspectos objetivos da realidade social de cada país. Nesse sentido, o objetivo ético da pesquisa é o de ajudar descredenciar práticas que visam obstaculizar a integração com base em teses infundadas e o de tentar evitar a reprodução desses 
discursos no ambiente acadêmico. Se Diez (2001) estiver certo ao afirmar que estão embutidos, mesmo em argumentos acadêmicos, narrativas discursivas que ajudam a constituir a realidade social, é certamente preferível corroborar para imagem de uma sociedade cosmopolita, tolerante e liberal - em que identidades são menos instrumentos de poder e mais estrutura de significação da realidade (Castells, 2001) - do que uma sociedade xenófoba e segregadora. Tudo isso, contudo, sem desconsiderar os desafios postos à liberdade identitária e sem se afastar da realidade social (inter)subjetiva. 


\section{Bibliografia}

Abdelal, R.; Herrera, Y.M.; Johnston, A.I.; McDermott, R. (eds.). (2009). Measuring Identity. Cambridge: Cambridge University Press.

Anderson, B. (1983 [2006]). Imagined Communities: Reflections on the Origin and Spread of Nationalism. London: Verso.

Aron, R. (1962). Paz e Guerra entre as Nações. Brasília: EdUnB, 2002.

Arquilla, John \& Ronfeldt, David (2001). Networks and Netwars. The Future of Terror, Crime, and Militancy. Pittsburg: RAND.

Ashley, R.K. (1986). "The Poverty of Neorealism” in Keohane, R. (ed.). Neorealism and Its Critics. Ithaca: Princeton University Pres. pp. 255-300.

Badie, B. (1995). O Fim dos Territórios. Lisboa: Instituto Piaget.

Bauman, Z. (2000). Modernidade Líquida. Rio de Janeiro: Zahar.

Bauman, Z. (2001). A Sociedade Individualizada. Rio de Janeiro: Zahar.

BBC. (2005). 'Polish plumber' beckons French. Disponível em: http://news.bbc.co.uk/2/hi/europe/4115164.stm. Acesso em 30/01/2011.

Berger, P.; Luckman, T. (1966). The Social Construction of Reality. NY: Polity Press.

Bobbio, N. (2000). Teoria Geral da Política. São Paulo: Elsevier.

Breuilly, J. (2000). “Abordagens do Nacionalismo”. in Balakrishnan, G. Um Mapa da Questão Nacional. São Paulo: Contraponto. pp. 156-184.

Buruma, I. (2007). Murder in Amsterdam: The Death of Theo Van Gogh and the Limits of Tolerance. London: Atlantic.

Castells, M. (1997). The Rise of the Network Society. New York: Routhledge.

Castells, M. (2002). O Poder da Identidade. Rio de Janeiro: Paz e Terra.

Cederman, L-E. (2000). Nationalism and Bounded Integration: What it Would Take to Construct a European Demos. European University Institute Working Papers, European Forum Series. RSC No. 2000/34. 
Checkel, J.T. (1998). The constructivist turn in international relations theory. World Politics, Vol. 50, No. 2. (1998), pp. 324-348.

Checkel, J.T.; Katzenstein,P.J. (2009). European Identity. Cambridge: Cambridge University Press.

Christiansen, T.; Erik, K.; Wiener, A. (2001). The Social Construction of Europe. London: Sage.

Cini, M; Borragán, N. (2010). European Union Politics. Oxford: Oxford University Press.

Cram, L. (2009). Identity and European Integration: diversity as source of integration. Nations and Nationalism. 15 (1). pp. 109-125.

Deutsch, K. (1966). Nationalism and Social Communication. Boston: Harvard University Press.

Deutsch, K. (1968). The Analysis of International Relations. New York: Prentice Hall.

Dias, F.S. (2003). As Teorias e o Papel das Idéias nas Relações Internacionais. Dissertação de Mestrado. Universidade de Brasília.

Diez, T. (2001). Speaking 'Europe': The Politics of Integration Discourse. in Christiansen et al. The Social Construction of Europe. London: Sage. pp. 85-100.

Evans-Pritchard, E.E. (1940). The Nuer: A Description of the Modes of Livelihood and Political Institutions of a Nilotic People. Oxford: Claredon Press.

Evans, G.; Newham, J. (1998). The Penguin Dictionary of International Relations. London: Penguin.

Fearon, J.; Laitin, D. (2000). Violence and the Social Construction of Ethnic Identity. International Organization 54, 4, Autumn 2000. pp. 845-877

Finzsch, N.; Schirmer, D. (1998). Identity and Intolerance: Nationalism, Racism, and Xenophobia in Germany and the United States. Cambridge, CUP.

Gabel, M.J.; Anderson, C.J. (2001). Exploring the European Demos (or lack thereof): the Structure of Citizen Attitudes and the European Political Space. CEuS Working Paper no. 2001/4

Geertz, C. (1977). The Interpretation of Cultures. New York: Basic 
Gellner, E. (1983). Nations and Nationalism. Ithaca: Cornell University Press.

Haas, P.M. (1992). Introduction: Epistemic Communities and International Policy Coordination. International Organization, 46:1, Winter 1992.

Hass, P.M. (1989). Do Regimes Matter? Epistemic Communities and Mediterranean Pollution. International Organization. Vol. 43. No. 3. The MIT Press Summer, 1989. pp. 377-403.

Hayek, F.A. (1960 [2006]). The Constitution of Liberty. Nova Iorque: Routledge.

Hobsbawm, E. (1990). Nations and Nationalism since 1780. Cambridge: Cambridge University Press.

Hobsbawm, E. (2007). Globalização, democracia e terrorismo. São Paulo: Cia das Letras.

Hurrell, A. (2007). On Global Order: power, values, and the constitution of international society. Oxford: Oxford University Press.

Jatobá, D. (2003). Teoria das Relações Internacionais: as inspirações sociológicas e as contribuições da abordagem teórica do construtivismo. Dissertação de Mestrado. Universidade de Brasília.

Keohane, R. (1984). After Hegemony: Cooperation And Discord In The World Political Economy. Princeton: PUP.

Kohler-Koch, B. (1997). Interactive Governance: Regions In The Network Of European Politics. Paper presented to the European Union Studies Association (EUSA), Biennial Conference. May 29-June 1, 1997, Seattle, WA. 37p.

Kymlicka, W. (1996). Multicultural Citizenship: A Liberal Theory Of Minority Rights. Oxford: Oxford University Press.

Lebow, R.N. (2001). Thucydides the Constructivist. The American Political Science Review, Vol. 95, No. 3 (Sep., 2001), pp. 547-560.

Marks, G. (1993). Structural policy and Multi-level governance in the EC. in Cafruny, A. \& Rosenthal, G. (eds.). The State of the European Community: The Maastricht Debate and Beyond. London: Boulder. pp. 391-411.

Martins, E. (2007). Cultura e Poder. São Paulo: Saraiva. 
Morgenthau, H.J. (1948). A Política entre as Nações. Brasília: EdUnB, 2002.

Nye, J.; Keohane, R. (1977). Power and Interdepence. Miami: Longman, 2001.

Nye, J.S. (2002). O Paradoxo do Poder Americano. São Paulo: EdUnesp, 2002.

OCDE. (2010). Multi-level governance: key facts. Disponível em: http://www.oecd.org/dataoecd/44/3/42410543.pdf. Acesso em 30/01/2011.

Onuf, N.G. (1989). World of Our Making: Rules and Rule in Social Theory and International Relations. Los Angeles: UNSCP.

Oye, K. (1986). Cooperation under Anarchy. Princenton University Press.

Preece, D.V. (2009). Dismantling Social Europe: The Political Economy of Social Policy in the European Union. Boulder: Lynne Rienner.

Putnam, R.D. (1988). Diplomacy and Domestic Politics: The Logic of TwoLevel Games. International Organization, Vol. 42(3), pages 427-60, Summer, 1998.

Renan, E. (1882). What is a Nation? in ELEY, G.; SUNY, R.G. (eds.). Becoming National: A Reader. Oxford: Oxford University Press, 1996. pp. 41-55.

Renouvin, P.; Duroselle, J-B. Introduction à l'histoire des Relations Internationales. Paris: Librairie Armand Colin, 1967.

Risse-Kappen, T. (ed.) (1995). Bringing Transnational Relations Back In: Non-State Actors, Domestic Structures and International Institutions. Cambridge: CUP.

Risse, T. (2010). A Community of Europeans? Transnational Identities and Public Spheres. Ithaca: Cornell University Press.

Ruggie, J.G. (1992). Multilateralism: the anatomy of an institution. International Organization, Vol. 46, No. 3 (Summer, 1992), pp. 561-598.

Ruggie, J.G. (1998). Constructing World Polity: Essays on International Institutionalization. New York: Routhledge.

Sartori, G. (1970). Concept Misformation in Comparative Politics. The American Political Science Review, Vol. 64, No. 4. (Dec., 1970). pp. 1033-1053.

Smith, A. (1991). The Ethnic Origins of Nations. New York: Willey-Blackwell. Smith, A. (1992). National Identity and the idea of European Unity. 
International Affairs. Vol 68, No. 1. pp. 55-76.

Smith, A. (1992). Nations and Nationalism in a Global Era. Cambridge: Polity Press.

Smith, S. (1995). "The Self-Images of a Discipline: A Genealogy of International Relations Theory". in Booth, K. \& Smith, S. International Relations Theory Today. Cambridge: Polity Press. pp. 1-38.

The Independent. (2002). Plea for leaders to reject nationalism. 22 de junho de 2002. Disponível em: <http://www.independent.co.uk/news/world/europe/plea-forleaders-to-reject-nationalism-646055.html>.

The Washington Times. (2004). Mini clash of civilizations. November 14, 2004. Disponível em: http://www.washingtontimes.com/news/2004/nov/14/20041114103944-4700r/. Acesso em 30/01/2010.

Timo, P. (2010). A Nacionalidade Na Fronteira: O Marco Jurídico-Político Dos Indígenas Guarani No Mercosul. Monografia de Conclusão de Curso de Graduação. Instituto de Relações Internacionais. Universidade de Brasília.

Von Mises, L. (1919). Nation, State, and Economy. Washington: Institute for Humane Studies.

Waever, O. (1996). The rise and fall of the inter-paradigm debate. In: Steve Smith, Ken Booth and Marysia Zalewski (eds). International Theory: Positivism and Beyond. (pp.149-185). Cambridge: Cambridge University Press.

Waltz, K.N. (1979). Theory of international politics. Nova Iorque: AddisonWeasley Publishing Company.

Wendt, A. (1987). The Agent-Structure Problem in International Relations Theory. International Organization, Vol. 41, No. 3 (Summer, 1987), pp. 335-370.

Wendt, A. (1994). Collective Identity Formation and the International State. The American Political Science Review, Vol. 88, No. 2 (Jun., 1994), pp. 384-396.

Wendt, A. (1998). On Constitution and Causation in International Relations. Review of International Studies 24:0505, 101-118, Cambridge University Press.

Wendt, A. (1999). Social Theory of International Politics. New York: Cambridge University Press. 


\section{Documentos Jurídicos}

Declaration on European Identity. Copenhagen, 1973.

Treaty establishing the European Community. Rome, 1957.

Treaty on European Union. Maastricht, 1992.

Treaty establishing a Constitution for Europe. Rome, 2004.

Tratado de Lisboa. Lisboa, 2007.

Decisão-quadro relativa à luta contra o racismo e a xenofobia. Bruxelas, 2008 


\section{APÊNDICE}

\section{DATAS DE REALIZAÇĀO DOS SURVEYS DO EUROBARÔMETRO}

\begin{tabular}{|cc}
\hline Série & Data (Ano/Semestre) \\
\hline EB17 & $1982 / 1$ \\
\hline EB19 & $1983 / 1$ \\
\hline EB24 & $1985 / 2$ \\
\hline EB27 & $1987 / 1$ \\
\hline EB29 & $1988 / 1$ \\
\hline EB31 & $1989 / 1$ \\
\hline EB33 & $1990 / 1$ \\
\hline EB36 & $1991 / 2$ \\
\hline EB37.0 & $1992 / 1$ \\
\hline EB40 & $1993 / 2$ \\
\hline EB42 & $1994 / 2$ \\
\hline EB43.0/.1 & $1995 / 1$ \\
\hline EB44.1/.2 & $1995 / 2$ \\
\hline EB46.0 & $1996 / 2$ \\
\hline EB47.1 & $1997 / 1$ \\
\hline EB49 & $1998 / 1$ \\
\hline EB50.0 & $1998 / 2$ \\
\hline EB52.0 & $1999 / 2$ \\
\hline EB53 & $2000 / 1$ \\
\hline EB54.1 & $2000 / 2$ \\
\hline EB56.2 & $2001 / 2$ \\
\hline EB61 & $2004 / 1$ \\
\hline EB62 & $2004 / 2$ \\
\hline EB64 & $2005 / 2$ \\
\hline EB73 & $2010 / 1$ \\
\hline & \\
\hline
\end{tabular}

